\title{
Isidro, el varón de Dios, como modelo de sincretismo religioso en la Edad Media*
}

\author{
MATILDE FERNÁNDEZ MONTES \\ Departamento de Antropología de España y América
} CSIC Madrid

\begin{abstract}
Fijaos en los pájaros del cielo, que ni siembran, ni siegan ni recogen en graneros, pero vuestro Padre celestial los alimenta. ¿No valéis vosotros más que ellos? ¿Y quién de vosotros, a fuerza de preocuparse, puede alargar un codo su vida? Y por el vestido, ¿a qué preocuparos? Observad los lirios del campo: ¡Como crecen! No se fatigan, ni hilan; $y$ os digo que ni Salomón en todo su esplendor se vistió como uno de ellos. Mateo 6, 26-29.
\end{abstract}

Dentro del panorama de santos cristianos medievales, San Isidro se presenta como un ejemplo de especial interés y singularidad; aquel humilde labrador que durante el siglo XII habitó en una villa recién tomada por los cristianos, ha terminado por convertirse no sólo en el patrón de los habitantes de la capital y de todos los campesinos, sino también en uno de los santos más populares en España, donde habrá muy pocas personas que no sean capaces de relatar al menos uno de sus milagros. Como patrón de Madrid ha sido objeto de atención de las más grandes personalidades del arte y la literatura, desde Lope de Vega, a Goya, mientras le rendía pleitesía la práctica totalidad de los monarcas españoles. Pero lo que sin duda es más importante, durante siglos y siglos, ha generado una intensa devoción popular que, rebasando ampliamente los límites de la capital y los devotos campesinos cercanos, le ha convertido en una figura con dimensión nacional. Entre otros santos españoles: mártires, fundadores de órdenes, grandes humanistas y místicos, San Isidro se presenta como un personaje mucho más simpático y próximo; un mediador de capacidad probada, especializado en el auxilio de las clases populares.

Como ante semejante difusión de su culto cabía esperar, el patrón de Madrid ha merecido numerosísimos estudios, sobre todo de manos de religiosos y madrileñistas, todos ellos creyentes, fervientes devotos y partidarios del santo, pero, sólo de manera esporádica y superficial, los antropólogos se han ocupado de él, normalmente en relación con su ro-

* El presente trabajo ha sido realizado dentro del proyecto de investigación PB 97-1182, Análisis antropológico de las manifestaciones del culto a santos y vírgenes de Madrid. 
mería, sin intentar el análisis hagiográfico que ahora nos proponemos ${ }^{1}$. En cualquier caso y aunque no pretendemos caer en las afirmaciones crédulas o entusiastas más generalizadas, nuestro acercamiento a su figura será sumamente respetuoso. No se trata de desmitificar o minusvalorar la repercusión de este personaje en la configuración de Madrid y los madrileños, sino por el contrario, reflexionar sobre él; ficción, historia y leyenda; tradición oral y escrita; encarnación cambiante a través de los siglos, capaz de adaptarse y dar respuesta a las necesidades de cada época y clase social son algunas de las claves que deben ser tenidas en cuenta.

Si tuviésemos que definir a San Isidro con un solo adjetivo este sería sin duda "madrileño". Un madrileño atemporal vinculado a la historia de la villa desde casi sus albores, que ha sabido adaptarse a las múltiples transformaciones sucedidas desde finales del siglo XI hasta el xx: labrador mozárabe, santo cristiano, pocero renacentista, patrón barroco de la sede de la corte, partidario de la ilustración, monárquico, franquista..., el santo ha estado siempre junto a los madrileños. Sin embargo es importante acentuar que no se trata de una personalidad oportunista, simplemente es el patrón y benefactor y para desempeñar este cargo con eficacia debe ser como la mayoría de los madrileños en cada momento. Ante el dilatado período de tiempo en que se ha desarrollado su culto y las múltiples transformaciones y análisis posibles, en el presente artículo nos ceñiremos a los milagros que realizó en vida, según el único documento medieval en que se recogen, reservando para una ocasión posterior, una monografía completa del patrón de Madrid.

De la época, con certeza, sólo contamos con el llamado Códice de Juan Diácono, origen o fuente de todas las biografías posteriores. Este códice estaba destinado a acompañar a un cadáver y explicar de quién era. El hoy conservado y venerado como cuerpo incorrupto de San Isidro $^{2}$ no ha sido sometido a ningún tipo de análisis para establecer su cronología y es posible que no sea de la misma antigüedad que el texto. Por otra parte, el arca primitiva, aunque medieval, por el análisis estilístico de los

1 Como excepciones que confirman la regla contamos con dos artículos de José Luis Mingote CALDERón, "Un milagro de San Isidro relacionado con ritos de protección del grano durante la siembra", RDTP, XLVIII (1993), pp. 135-153 y "Ángeles labradores y Lamias. Una visión mítica del trabajo agrícolan, I Jornadas Internacionales sobre Tecnología Agraria Tradicional (Madrid: Museo Nacional del Pueblo Español, 1992), pp. 65-81.

2 En realidad hablar del cuerpo incorrupto de éste, al igual que de otros santos, no deja de ser una percepción algo triunfalista de la realidad. El cuerpo está y ya lo estaba, según descripciones, en los siglos XVI y XVII, "momificado", "amojamado", o "apergaminadon. 
motivos ornamentales, se debe datar en el último tercio del siglo XIII o primera mitad del $\mathrm{XIV}^{3}$, es decir, tiene sesenta o setenta años menos de lo que la tradición supone (se atribuye a la época de Alfonso VIII, quien la habría donado como agradecimiento al santo, por su intercesión en la batalla de las Navas de Tolosa). El arca está decorada con pinturas en las que se representan cuatro de los cinco milagros relatados en el códice (parece probable que el quinto se hallara en la tapa, donde los dibujos están casi totalmente perdidos resultando irreconocibles) lo que, a nuestro juicio refuerza su cronología posterior.

\section{EL CÓDICE DE SAN ISIDRO}

Tratar y aun sólo pretender tratar del Códice del Diácono Juan sobre la vida, fama, virtudes, santidad y milagros del glorioso Señor San Isidro Labrador, es como querer meter la mano en un avispero. [...] Son tantos los interrogantes, que acerca de este códice han suscitado los críticos y por cierto de buena talla, que señalar uno equivale a promover y remover otros, y al final merecer el fruto y la paga de una sonrisa escéptica o alguna frase o gesto de conmiseración.

Nicolás Sanz Martínez ${ }^{4}$ inaugura con esta frase plenamente acertada, el mejor de los estudios sobre el único documento medieval dedicado al santo, cuya problemática formal vamos a resumir brevemente antes de introducirnos en el análisis etnohistórico de su contenido.

En primer lugar, debemos señalar que se trata de un manuscrito anónimo escrito en latín medieval que, como veremos detalladamente, más que de biografía o hagiografía debe tildarse como "relación de milagros". Su denominación habitual: "Códice de Juan Diácono" se debe a que, tras relatar uno de los prodigios póstumos fechado en 1232, se añadió:

Yo Juan, un humilde diácono, y muchos otros, tal como lo oímos de su boca, lo hemos contado de forma sencilla en la presente cédula ${ }^{5}$.

3 Carmen PRIEGo (dir.), Museo de San Isidro. Arqueología y Tradición (Madrid: Ayuntamiento de Madrid, 1994), p. 7.

4 Nicolás SAnz MarTínez, "El Códice de Juan Diácono", San Isidro Labrador patrono de la Villa y Corte. IX Centenario de su nacimiento (Madrid: Academia de Arte e Historia de San Dámaso, Arzobispado de Madrid-Alcalá, 1983), pp. 49-69.

5 Los milagros de San Isidro (s. XIII) (facsímil del Códice). Transcripción de Fidel FITA revisada por Quintín ALDEA. Traducción por Pilar Saquero Suarez-Somonte y Tomás González Rolán (MADRID: Academia de Arte e Historia de San Dámaso, Arzobispado de Madrid, 1993), p. 124. Todas las citas del códice están tomadas de esta edición que a su vez reproduce la única transcripción que se ha editado del texto, realizada 
Con bastante claridad, la mención parece señalar al testigo de un episodio concreto, o al narrador oral de éste, consignado nominalmente para avalar o autentificar la información, al igual que, en otros casos, se puso el nombre y apellido u oficio del beneficiario. Sin embargo, desde el siglo XVI, las hagiografías y estudios (incluida la documentación generada en el proceso de canonización) citan a "Juan Diácono" — con el cargo eclesiástico puesto tras el nombre a modo de apellido- como autor, si no de todo, al menos de las primeras partes del manuscrito.

Fidel Fita ${ }^{6}$ identificó al personaje con el franciscano Juan Gil de Zamora, preceptor del infante Don Sancho, basándose, además de en los nombres coincidentes, en la erudición religiosa vertida en el documento (con abundantes citas bíblicas, especialmente del Nuevo Testamento). También adujo las frecuentes alusiones a los franciscanos y las coincidencias cronológicas. Juan Gil de Zamora había escrito una colección de hagiografías que lamentablemente no se conserva, entre las cuales bien hubiera podido incluirse la de San Isidro. Esta adscripción, aceptada por la mayoría de los críticos y estudiosos, sólo en nuestros días ha sido refutada por Nicolás Sanz Martínez ${ }^{7}$, quien adjudica la autoría a un "Juan" que fue diácono en la iglesia de la Almudena en las fechas del escrito. Su alejamiento de la postura comúnmente admitida se basa en que Juan Gil de Zamora era un personaje principal, no un humilde diácono y no hubiera utilizado la expresión "ego" sino "nos". Tampoco le parecen significativas las alusiones a los franciscanos, puesto que en aquella época el clero religioso en Madrid era fundamentalmente de esta orden y, además, al mencionarlos no dice en ningún momento que él perteneciera a la misma. Sin restar verosimilitud a esta nueva posible autoría volvemos a recordar las palabras con que iniciamos este apartado: el manuscrito es anónimo. Sin duda debió pertenecer al clero la persona-iautor? que recogió una tradición oral previa, la escribió en latín y completó con nuevas series de milagros y citas bíblicas, pero identificarla con aquel humilde diácono Juan, testigo de un milagro carece de cualquier tipo de solidez ${ }^{8}$.

Lo cierto es que con un somero análisis de las veintiocho hojas de

por Fidel FITA, "Año 1275. Leyenda de San Isidro por el diácono Juan. Códice del siglo XIII, procedente del archivo parroquial de San Andrés", Boletín de la Real Academia de la Historia, IX (1886), pp. 97-157.

6 Op. cit., pp.101-102 y 156-57.

7 Op. cit., pp. 55-60.

8 Manuel C. DíAz y DíAz, "Nótula sobre el manuscrito de la leyenda de San Isidro", San Isidro Labrador patrono de la Villa y Corte... op. cit., pp. 45-48, es el único que alerta sobre la falta de solidez de la identificación de "Juan Diácono" con el autor del texto. 
pergamino que forman los tres cuadernos ${ }^{9}$, tan sólo ateniéndonos al tipo de caligrafía, se distinguen dos manos o sectores diferentes. El primero contiene el relato de cinco milagros acaecidos durante la vida del santo, su muerte y el entierro en el cementerio de San Andrés. Es lo que se podría denominar "la leyenda de San Isidro", ya que la transmisión oral de los acontecimientos es la única fuente de información aducida. Destaca la ausencia casi total de datos biográficos o cronológicos. Nada se dice de su fecha de nacimiento, ni tan siquiera de la de su muerte, mucho más importante en las hagiografías cristianas y musulmanas, tampoco el nombre de su mujer e hijo, a los que efectivamente se alude, y mucho menos de sus padres, o su amo.

Cuarenta años después del fallecimiento, continúa este sector con lo acontecido durante la translación del cuerpo al interior de la iglesia de San Andrés, y una serie de milagros póstumos que sucedieron hasta 1271. Aquí, la precisión cronológica y onomástica sobre los beneficiarios parece indicar la coetaneidad del autor con las fechas reseñadas. Finaliza la primera parte con los textos de oficio en honor del santo; es decir una serie de himnos dedicados a él, que se cantarían en el interior del templo. Hasta aquí, todo está escrito por una misma persona, de manera más o menos ininterrumpida (como lo demuestran no sólo el tipo de caligrafía, sino también los colores de las tintas que iluminan las iniciales de las primeras palabras de cada párrafo). Sin embargo, y retomando la problemática de la probable existencia de uno o varios narradores orales, además de un autor que compondría y latinizaría el texto y un escribano que lo pasó a limpio, Nicolás Sanz Martínez ${ }^{10}$, piensa que los himnos no fueron compuestos por Juan Diácono sino que son posteriores, aunque sí pertenecen al mismo escribano.

Las hojas finales del documento quedaron en blanco y, años después, se añadió otra serie de milagros póstumos cuya última fecha es 1275 . Frente a la sección anterior, además de las pequeñas variaciones caligráficas y ornamentales se distingue por contener narraciones más breves, aunque de gran precisión onomástica y con una mayor variedad social de beneficiarios. El prodigio que cierra esta segunda parte en realidad pertenece a la primera, pero el escribano o copista por mencionarse que era el último, lo cambió de lugar. Todavía quedaron en blanco algunas hojas

9 La descripción formal del documento ha sido publicada por Fidel FITA, 1886, op. cit., p. 100; Manuel C. Díaz y Díaz, op. cit. y Tomás Marín y María luisa Palacio, "Comentario codicológico", Los milagros de San Isidro (s. XIII) (facsímil del Códice), op. cit.

10 Op. cit., p. 54. 
que no fueron empleadas hasta el siglo Xv cuando en 1421 y 1426, dos presbíteros de San Andrés añaden, en castellano y latín respectivamente, las narraciones de un acta notarial de apertura del sepulcro y reconocimiento del cadáver y el relato de una rogativa para pedir lluvias.

Todo el documento es de gran calidad gráfica con las iniciales coloreadas, aunque contiene varias erratas, como el olvido de alguna letra o pequeñas confusiones que parecen indicar que se trata de una copia que, por la caligrafía de las notas musicales incluidas en los himnos, muy parecida a la de las Cantigas a Santa María de Alfonso X El Sabio, debemos situar a finales del siglo XIII, lo que coincide con 1275, última fecha señalada en el escrito. Nunca podremos saber si cada uno de los apartados de los dos sectores se generaron y escribieron en un original no conservado con anterioridad, lo que ha motivado la afirmación generalizada $^{11}$ de que el destino del manuscrito ha sido acompañar a las reliquias y no la divulgación o propaganda (se carece de cualquier otro tipo de copia de esta época). Sin embargo pensamos que la primera parte, es decir, lo relatado hasta el entierro de San Isidro y su traslado al interior de la Iglesia de San Andrés está concebido para su lectura en público. Sus destinatarios medievales, normalmente serían analfabetos (al estar en latín debemos pensar que se trata de una traducción de un relato en lengua romance o que se leería ante los miembros de una orden religiosa). Con facilidad se pueden apreciar numerosos recursos retóricos y dramáticos, como el énfasis en determinadas oraciones, los vivos diálogos, las indicaciones anecdóticas y puntuales que tratan de concretar y dar verosimilitud a la historia, etc. ${ }^{12}$

\section{EL LEGADO HISTÓRICO Y CULTURAL DEL MADRID DE SAN ISIDRO}

Aunque la leyenda de San Isidro carece de cronología, por algunas fechas de los milagros póstumos y la referencia de que el cuerpo estuvo enterrado cuarenta años en el cementerio de San Andrés antes de su traslado al interior de la iglesia, se ha calculado que el fallecimiento se produjo en 1172. La tradición que siglo tras siglo ha ido completando y creando una auténtica hagiografía mantiene que murió a los noventa años, edad

11 Sostenida entre otros por Zacarías GARCía VILLADA, San Isidro Labrador en la bistoria y en la literatura (Madrid, 1922), pp. 7-9, Fidel FITA, op. cit., y Nicolás SANZ MARTÍNEZ, op. cit.

12 Evelyn BIRGE VITZ, "From the Oral to the Written in Medieval and Renaissance Saints Lives", Renate Blumenfeld-KosinSKI and Timea Szell (eds.), Images of Sainthood in Medieval Europe (Ithaca and London: Cornell University Press, 1991), pp. 97-114. 
mítica de muchos héroes y santos. Las cifras salen redondas situándose así su supuesto nacimiento el cuatro de abril de 1082 (festividad de San Isidoro, a quien debería el nombre), precisamente uno o tres años antes de la toma de Madrid por los reinos cristianos, según se considere que fue conquistada por Alfonso VI en el 1083, al mismo tiempo que Toledo, o, como sostienen algunos historiadores, pocos años después, en 1085.

Desde nuestra posición, algo más prudente, sólo podemos verificar que en el siglo xill se puso por escrito el relato de un personaje legendario cuya vida transcurrió al menos un siglo antes, aunque pudiera ser incluso de épocas anteriores, habiéndose mantenido su recuerdo durante todo este tiempo, tan sólo por tradición oral. Debemos recordar que en las hagiografías basadas en este tipo de fuentes, las fechas se redondean ajustándose a los intereses del narrador y las expectativas de los oyentes. Con las adjudicadas, nuestro santo habría desarrollado su existencia en un Madrid cristiano, aunque no exento de relaciones con el inmediatamente anterior de carácter islámico.

Thomas J. Heffernan ${ }^{13}$ afirma que cuando los biógrafos de historias sagradas escriben sobre personajes de tiempos pasados, ambas épocas se funden y entran en diálogo. El flujo entre los dos momentos históricos es parte del objeto de la hagiografía sagrada, cuya principal premisa es documentar la continuidad de los modelos de conducta del pasado, como pertenecientes a los del presente. En nuestro caso, como veremos más detalladamente son muchos los anacronismos que confirman la mezcla y superposición de los patrones culturales del Madrid cristiano del siglo XIII, con los del XII, cuando, no sólo la huella de los tres siglos de dominación islámica era bien patente, sino que además se alternaron períodos de dominio de uno y otro bando, hasta la cristianización definitiva, tras la ocupación de la villa por Fernando II en 1162. Incluso hemos encontrado en nuestro análisis vestigios de los modelos de santidad islámica medieval a los que prestaremos una especial atención.

Las primeras noticias históricas de Madrid datan del siglo IX; los reinos cristianos que habían alcanzado y fortificado la línea del Duero, en su expansión hacia el sur, en el 860 toman fugazmente Talamanca. Ante la proximidad del peligro, se construyen una serie de torres vigías o atalayas protegiendo la Marca Media (amplio espacio, tierra de nadie que separa los reinos cristianos de los islámicos, y que en nuestro ámbito ocupa las cumbres del Guadarrama). Este sistema defensivo se completaba con una serie de fortalezas que protegían las poblaciones más meridionales,

13 Thomas J. HeFFERnAN, Sacred Biography. Saints and Their Biographers in the Middle Ages (New York: Oxford University Press, 1988), pp. 22-23. 
situadas en la desembocadura de los ríos. Entre éstas destaca la construcción por Muhamad I de un alcázar con un doble recinto amurallado; una primera cerca para la fortaleza militar y la segunda que acogía un pequeño poblado visigótico, situado junto a un manantial-arroyo de buenas y abundantes aguas llamado Matrice (matriz de agua) cuyo nombre tomará la población que sustenta. Los musulmanes crean así una plaza fuerte que conservó la denominación primitiva, aunque traducida al árabe Magerit o Maȳrit. Subordinada a Toledo ejerció la capitalidad de la zona de choque de la Marca Media y además, por su carácter bélico, se constituyó en rïbat, es decir, en un lugar de destino para los peregrinos islámicos que cumplen el precepto de la guerra santa. Como estudió Jaime Oliver Asín ${ }^{14}$, el Madrid árabe pronto alcanzó un cierto florecimiento adoptándose técnicas de origen oriental, como el sistema de captación de aguas subterráneas, en uso hasta el siglo XIX, o la creación de numerosos huertos y jardines. Además se constata la afluencia de musulmanes ilustres no sólo guerreros, sino también literatos y científicos; siendo relativamente frecuentes las referencias al origen madrileño de determinados personajes citados en fuentes árabes, a la vez que acuden a la ciudad personalidades del resto del mundo islámico.

La población campesina madrileña, mayoritariamente de origen bereber y escasa tradición ciudadana, con sus creencias preislámicas y desviaciones de la ortodoxia oficial parecía siempre propicia a escuchar la predicación subversiva y fue objetivo predilecto de los misioneros fatimíes ${ }^{15}$. De hecho en Madrid, al-Mahdī 'Ubayd Allāh, un esclavo, se levantó haciéndose pasar por el jefe de la secta; aún sin obtener credibilidad fue ejecutado. Llamamos la atención sobre este personaje, porque muestra la existencia de una rebeldía político-religiosa entre las clases populares madrileñas de principios del siglo $\mathrm{x}$. A finales del mismo, otro individuo que habitó en la villa fue Ŷassās al-Zāhid que se dedicaba a explicar un libro de ascética del santo turolense Yumn Ibn Rizq, combatiente de frontera y tipo milagrero, de quien se decía que, a pesar de ser pobre, siempre podía dar limosnas y comprar lo que quería, sólo con meter la mano debajo de una estera de donde milagrosamente salían las monedas. De él también

14 Jaime OLIVER ASín, "El ambiente cultural y militar del Madrid musulmán", Revista de la Biblioteca Archivo y Museo (Ayuntamiento de Madrid) n. ${ }^{\text {s }}$ 61-62 (1951), pp. 259-288. Del mismo autor resulta esencial Historia del nombre de Madrid (Madrid: CSIC, 1959).

15 Jaime Ouver Asín, op. cit., 1951, pp. 280 y ss. El imperio fatimí fue creado por al-Mahdī Ubayd Allāh que con pretensión de ser el verdadero descendiente del profeta a través de su hija Fátima, se proclamó jefe espiritual del Islam y se hizo señor absoluto del Norte de África, imperio que dominó entre el 909 y el 934. 
se contaba que a la hora de la oración, todo el mundo le veía en la mezquita cuando en realidad donde estaba era en su casa. Por último resulta de especial interés para nuestro estudio, el santo toledano Abū-I Walìd Yūnus Ibn Ahmad Ibn Yūnus al-Azdì, conocido como Aben Chueco o Aben Choco, un ascético afectuoso y de buen carácter con sus discípulos, siempre recluido en su casa, que murió en Madrid el siete de diciembre de $1081^{16}$. Aunque, como ya hemos dicho, la fecha del nacimiento de San Isidro, el cuatro de abril de 1082, no es más que una tradición debemos destacar que se sitúa pocos meses después del fallecimiento del último santo musulmán establecido en la villa, lo que se ajustaría a los requisitos de la santidad islámica, ya que los santos reconocidos en vida tienen sus discípulos y, al morir, su "baraka" o "gracia" se traspasa a uno de ellos que le sucede. El siglo XI es una fecha demasiado prematura para la creación de linajes de santos ${ }^{17}$, y suele ser alguno de los discípulos y no sus descendientes quien hereda el carisma. Cuando nació Isidro, los "madrileños" no sólo estaba familiarizados con los conceptos de la mística y la santidad islámica, sino que incluso habían contado con los favores y beneficios proporcionados por la presencia de un santo, que lógicamente procurarían mantener con otro.

Los hagiógrafos que narran vidas de tiempos anteriores al suyo tienden a dar todo tipo de detalles y recrear el momento histórico en el que vivió la figura biografiada en busca de una mayor verosimilitud de sus relatos ${ }^{18}$. Así, en los siglos XV y XVI se incorporó el origen mozárabe de los padres de San Isidro, al igual que el amplio relato de su huida y estancia en Torrelaguna para evitar vivir en Madrid, cuando cayó nuevamente bajo el dominio islámico, durante el XII. Nada de esto es mencionado en el códice medieval, mientras, por el contrario está atestiguada la coexistencia pacífica de mozárabes en la villa árabe y de mudéjares en la cristiana. Lo cierto es que, si realmente los padres de San Isidro hubieran sido una pareja de campesinos mozárabes que habitaron en Madrid durante la segunda mitad del siglo XI, el tipo de cultura y creencias que transmitirían a su hijo no diferiría demasiado de las recibidas si hubiesen sido musulmanes creyentes. Conviene recordar que los mozárabes del xI, tras tres siglos de existencia en contacto con otra cultura dominante habían llegado a toda clase de herejías y turbulencias teológicas. La crisis espiritual debida a su aislamiento y vaciado dogmático, les llevó a la in-

\footnotetext{
16 Jaime Oliver Asín, op. cit., 1951, pp. 285-286.

17 Halima Ferhat et Hamid TRIKI, "Hagiographie et religion au Maroc mediéval", Hespéris Tamuda, XXIV (1986), pp. 17-52, p. 21.

18 Thomas J. HefFernan, op. cit., p. 43.
} 
tegración en la sociedad musulmana, abandonando la ortodoxia cristiana y multiplicándose los matrimonios mixtos en un claro proceso de sincretismo cultural que afectó con mayor intensidad a las clases campesinas ${ }^{19}$. Los musulmanes no sólo toleraban la presencia de cristianos o judíos en sus poblaciones, sino que incluso la favorecían; establecidos en barrios periféricos y sujetos a tributaciones especiales, se constituían en unos útiles ciudadanos de segunda categoría, dedicados a la agricultura en el caso de mozárabes, y a las artesanías y oficios en el de judíos. Isidro y probablemente también sus padres vivieron en el arrabal de San Andrés en cuyo cementerio fue enterrado. La hagiografía del santo patrón ha tenido tanto peso en la configuración de Madrid que varios historiadores, aunque aduciendo la "tradición" en vez de fuentes históricas ${ }^{20}$ localizan allí la comunidad mozárabe de la villa, añadiendo que la iglesia de San Andrés fue la única dedicada al culto cristiano en el Madrid musulmán. Lo cierto es que esta parroquia situada junto a la Puerta de Moros es el lugar donde se situan los mudéjares tras la cristianización; un barrio de campesinos del que las excavaciones arqueológicas han proporcionado restos de tradición u origen musulmán ${ }^{21}$, fechados en los siglos X, XI y XII.

Campesino mozárabe o musulmán de origen bereber, Isidro heredó unas creencias y supersticiones contaminadas por otras religiones o culturas con las que ambas tradiciones habían tenido fuertes contactos antes $o$ durante su largo asentamiento en el alejado enclave madrileño.

\section{LA LEYENDA HAGIOGRÁFICA DEL BIENAVENTURADO ISIDRO ${ }^{22}$}

De las diversas partes del códice, sin duda la de mayor interés es la primera y más primitiva que se ocupa de la vida de Isidro propiamente

19 Miguel José HaGerTy, Los cuervos de San Vicente. Escatología mozárabe (Madrid: Editora Nacional, Biblioteca de Visionarios Heterodoxos y Marginados, 1978), pp. 19 y ss.

20 Pedro Montoliu, Madrid Villa y Corte. Historia de una ciudad (Madrid: Sílex, 1996) p. 47. Manuel Montero VALlejo, Madrid, musulmán, cristiano y bajo medieval, (Madrid: Ed. Avapiés, 1990), pp. 72 y 90.

21 Carmen Priego (dir.), Museo de San Isidro. Arqueología y Tradición (Madrid: Ayuntamiento de Madrid, 1994), p. 10. El texto está firmado por cuatro miembros del Departamento de Conservación de Edificios que como ya hicieran los historiadores piensan que la aparición de restos de los siglos x y XI confirma la existencia de un arrabal hispanoárabe. Pero sus habitantes también podrían ser los campesinos proletarios bereberes que poblaron Madrid y lógicamente vivirían a las afueras, junto a las puertas de las murallas que daban acceso a los campos de labor.

22 El patrón madrileño no fue canonizado hasta 1622 por lo que preferimos no tildarle de santo, sino como normalmente se hace en el códice, de "el siervo de Dios", "el varón de Dios" o "el bienaventurado Isidro". 
dicha (el resto son los milagros póstumos y los himnos que se cantaban en su honor). Es lo que se denomina "la leyenda de San Isidro", ya que el único aval esgrimido para certificar la información es la tradición oral, a la que ya se alude en dos ocasiones al inicio del documento:

En Madrid perdura el recuerdo del bienaventurado Isidro [...] según he sabido por lo que cuentan los hombres de buena fe $[\ldots]^{23}$.

Por si esta menciones genéricas no fueran suficientes, al final de varios de los milagros, se puede leer:

[1.ํ] Y después de despedirse, volvió a su casa y contó a muchos conciudadanos lo que le había ocurrido. Por ello, este milagro del Santo, entre otros, quedó más profundamente grabado en la memoria de todos hasta el día de hoy.

[2. ${ }^{\circ}$ Pero no se atrevió a comunicar a su marido lo ocurrido, pues sabía que él desdeñaba la vanagloria. Sin embargo, puesto que los que arden en el amor de Dios no deben callar en los asuntos referentes a Él, no quiso, puesto que no debía, ocultarlo a los vecinos y otras personas honorables, en la medida en que Dios le había indicado contarlo. Y esto, tal y como se nos contó por testigos fehacientes, lo hemos juzgado digno de ser relatado.

[3. $\left.{ }^{\circ}\right][. .$.$] al ver el milagro obrado de repente, quedaron extraordinariamente asom-$ brados y por el momento guardaron silencio, reservando la noticia para mejor ocasión, [...] Y así, convencidos de que se trataba de un auténtico milagro del Dios verdadero, contaron fielmente lo que había sucedido a muchos hombres y mujeres, no sólo en el campo, sino también en la Villa, para que hubiese muchos testigos y muchos ensalzadores de Dios ${ }^{24}$.

Aunque a finales del siglo xiII, fecha del manuscrito, la tradición oral ha perdido prestigio como modo de verificar y autentificar las hagiografías, el autor del códice desdeña las objeciones más obvias. Así, en el segundo párrafo reproducido, no duda en clasificar como "testigos fehacientes" a las personas que le han narrado el milagro, aunque sólo lo presenció la esposa, quien se lo contó a "vecinos y personas honorables", habiéndose transmitido únicamente por vía oral, durante varias generaciones, desde estos últimos hasta los coetáneos al responsable del manuscrito. Asimismo, en el último párrafo arriba reproducido, se considera "testigos" a las personas que oyeron la narración de primera mano pero sin presenciarla.

23 Los milagros de San Isidro (siglo XIII), op. cit., p. 115.

24 Ibid.: [1으, p. 118, segundo milagro: los bueyes aran sin ayuda humana. [2으 p. 119, cuarto milagro: en su casa, la esposa de San Isidro es testigo de una multiplicación milagrosa de alimentos para un pobre. [3으, p. 120, quinto milagro: los miembros de una cofradía asisten a la multiplicación milagrosa de los alimentos para su repartición entre los pobres. 
Aviad M. Kleinberg ${ }^{25}$ afirma que cuando un santo comienza a tener un lugar en la memoria de una comunidad, su imagen sufre una serie de cambios. El hombre de vida cotidiana con sus ambiguos y contradictorios mensajes, con sus defectos y virtudes es gradualmente sustituido por una creación más coherente. La tradición oral simplifica al santo. Los que las comunidades cristianas tenían antes del siglo XII emergían, como San Isidro, de forma espontánea tras su muerte, gracias al reconocimiento y culto recibido por los miembros de su localidad. Pero el biógrafo necesita alguna evidencia de la santidad y esta es proporcionada haciendo que cada figura se represente como una manifestación específica de una vida prototípica, un santo y sus milagros son casi idénticos a otros ya reconocidos. La mayoría de las hagiografías anteriores al siglo XI tratan de convencer a su público de que el santo que tratan hace lo mismo que otros ya reconocidos y por tanto también debe serlo. Sólo en las versiones más primitivas se pueden encontrar elementos irrelevantes o potencialmente peligrosos; así, las primeras biografías, antes del reconocimiento universal de su condición, rara vez son el estereotipado producto en que se convierten con el paso del tiempo. El hagiógrafo contemporáneo o que escribe poco después de la muerte, se encuentra en una disyuntiva: por una parte conoce los modelos canónicos, las biografías consideradas como clásicas y quiere que la suya se parezca a ellas para mostrar que su santo rememora las grandes figuras del pasado, pero, por otra parte sabe las diferencias entre estos modelos y su personaje y muchos de los que hablaron con él no encuentran un claro mensaje moral. Sin embargo, estos prototipos o modelos de santidad son reinterpretados en cada caso concreto: milagros similares, frases similares, gestos similares pueden tener distintos significados en distintos contextos.

La leyenda de Isidro, el hombre de Dios, contiene suficientes referencias biográficas para trazar las principales características de su personalidad y establecer paralelos y comparaciones con los modelos de santidad vigentes en la época. Las que se consideraron más significativas se proporcionan en un escueto párrafo inicial:

En Madrid perdura el recuerdo del bienaventurado Isidro, gloriosísimo testigo de nuestro Señor Jesucristo, el cual, aun siendo un sencillo labrador, era tenido por devoto del Señor y afable con sus semejantes; como seguidor no descuidado, sino escrupuloso de las Sagradas Escrituras, anteponía no lo temporal a lo espiritual sino lo espiritual a lo temporal. En efecto, cada día, según he sabido por lo que cuentan los hombres de buena fe, muy de mañana dejaba la faena de la labranza

25 Aviad M. KLeINBERG, Prophets in their own Country. Livin Saints and the Making of Sainthood in the Later Middle Ages (Chicago and London: The University of Chicago Press, 1984), pp. 1-35. 
e iba a rezar a muchas iglesias de Dios y, aunque asombrosamente se pasaba gran parte del día orando, mientras que sus convecinos atendían sus obligaciones, él aprestándose el último, pero diligente en su deber, con la ayuda de Dios, superaba el ahínco de los demás, recordando las palabras del Apóstol: “Haz siempre algo, para que el diablo te encuentre ocupadon ${ }^{26}$.

Por los relatos de los milagros sabemos algunos detalles más, como su humildad y "paciencia", que estaba casado y tenía un hijo, o que eligió vivir del trabajo de sus propias manos, como siervo en campos ajenos. Un humilde siervo, labrador, laico, casado y padre que antepone el rezo en las iglesias a sus obligaciones, sin que esto, (empleando una expresión moderna) constituya una merma de su productividad. Su leyenda se forjó y transmitió oralmente durante varios siglos de la Edad Media, probablemente desde el Madrid musulmán del XI, hasta el cristiano del XIII. ¿A qué modelo, o modelos de santidad responde San Isidro? Aunque al analizar cada milagro ampliaremos los paralelos y comparaciones, nos parece de interés basándonos sólo en esta caracterización inicial, tratar de buscar sus prototipos medievales tanto islámicos, como cristianos.

Lo primero que se nos dice es que Isidro era un sencillo labrador; poco o nada tiene que ver con los ejemplos europeos del XI y primera mitad del XII: "distantes, nobles, heroicos, admirables e inimitables" ${ }^{27}$, casi exclusivamente personajes eclesiásticos, aristócratas o reyes y reinas, como con acertada expresión señala Brigitte Cazelles. Según André Vauchez ${ }^{28}$ en los siglos x y XI, ciertamente se puede apreciar un aumento de los santos laicos, aunque éstos difieren bastante de Isidro por su origen aristocrático o incluso real. Sin embargo desde la segunda mitad del siglo XI, la reforma gregoriana desarrolló un nuevo monasticismo mucho más espiritual que impidió la difusión hagiográfica a los laicos, la santidad implica un abandono de los intereses terrenales: familia, profesión o cualquier tipo de relación social. Sólo los laicos eremitas lograrán una valoración positiva.

También se dan casos de santos caballeros o santos soldados que combaten en España o en Tierra Santa. En 1109, los almorávides llegaron a Madrid asentándose en el Campo del Moro, el códice desaprovecha la oportunidad de convertir al patrón en un santo-soldado o guerrero que lucha contra los infieles en su propia ciudad. No se trata de una torpeza

26 P. 115

27 Brigitte CAZELLES, "Introduction", Images of Sainthood in Medieval Europe, op. cit., pp. 2 y 3.

28 André VAuCHEZ, "Lay People's Sanctity in Western Europe: Evolution of a Pattern (Twelfh and thirteenth centuries)", Images of Sainthood in Medieval Europe, op. cit., pp. 21-32. 
o falta de conocimiento histórico; como afirma Aviad M. kleinberg ${ }^{29}$, se debe estudiar e investigar el proceso sociológico ocurrido entre el santo, por una parte y las expectativas de una audiencia perteneciente a un momento y un lugar determinado, por la otra. El santo define los ideales de una comunidad y los madrileños del XII, moros, judíos y cristianos habían logrado desarrollar una convivencia pacífica y equilibrada que pretendían perpetuar, más que dedicarse a las luchas y aniquilaciones de unos por otros ${ }^{30}$. Isidro se presenta como un pacifista y conciliador que no toma partido a favor o en contra de ninguna de las tres culturas, independientemente de cual de ellas detente el poder. En este sentido, su no intervención se podría considerar como una actitud política, comparable a la labor de mediación y pacificación entre las tribus bereberes asentadas y las trashumantes que Gellner definió como la principal característica de los santos del Atlas ${ }^{31}$. También entre los cristianos que llegan a ser patrones en ciudades donde conviven varios grupos culturales, se ha apreciado este papel conciliatorio como lo desempeñaron en 417, las reliquias de San Estefan llegadas a Mahón, el cual pronto fue reconocido como patrón de las comunidades judía y cristiana ${ }^{32}$.

Durante el siglo xII el paralelismo entre nobleza de cuna y santidad se mantiene en el Norte de Europa, pero en las regiones mediterráneas se difunde la práctica de venerar a plebeyos, especialmente miembros de la clase media y artesanos, como Santo Domingo de la Calzada que reparó con sus propias manos el camino a Santiago de Compostela. El fenómeno difundido sobre todo en las zonas urbanizadas del centro y norte de Italia dio como fruto santos labradores, artesanos o negociantes, de clase media o baja y sensibilizados ante la nueva realidad económica y social. Cita Vauchez ${ }^{33}$ como representativas las vidas de San Teobaldo de Alba († 1150) portero, Rainiero de Pisa, hijo de navegante y ermitaño, Raymond Palmeiro $(\dagger 1200)$ un simple jornalero y tendero que fue en peregrinación a Jerusalén y luego fundó un hospital para pobres y Homobono de Cremona, mercader que combatió varias herejías ( $†$ 1197).

29) Aviad M. KleINBERG, op. cit., p. 34.

30 Siglos más tarde, en el XVI y XVII, cuando la intolerancia religiosa y cultural toma cartas de naturaleza en la España cristiana, los hagiógrafos de la época añadieron que San Isidro huyó a Torrelaguna para evitar vivir en un Maclrid dominado por los musulmanes.

31 Ernest Gellner, Saints of the Atlas (London: Weidenfeld and Nicolson, 1969), pp. $136 \mathrm{y}$ ss.

32 Peter BROwn, The cult of the saints. Its Rise and Function in Latin Christianity (Chicago, University of Chicago Press, 1981), pp. 103 y ss.

33 Op. cit. , pp. 27-28. 
Todos ellos fueron peregrinos o ascetas, siendo más importante que su devoción el servicio a los vecinos; ni su trabajo, ni su vida conyugal o familiar añadieron nada a su perfección cristiana, sino que, por el contrario, se presentan como obstáculos para su desarrollo espiritual. Se insiste en su virginidad o castidad como manera de imitar a Cristo. Dentro de este grupo es donde mejor encaja Isidro cuyos paralelos con Homobono son enormes. Este último, adquirió gran popularidad tras su canonización en 1199 y es el primer santo laico medieval reconocido por la Iglesia que no fue miembro de la nobleza ${ }^{34}$. Como San Isidro era muy dado a la oración, tanto de día como de noche y acudía cotidianamente a la iglesia de San Gil para asistir a los maitines, estaba casado y era muy generoso con los pobres, hasta el punto de provocar la inquietud y los reproches de su esposa. Asimismo se menciona su enorme humildad que le llevaba a silenciar sus prodigios, entre los que se encuentran multiplicaciones de alimentos. Pero, sin negar estos paralelos, que al tratar más detalladamente cada uno de los milagros ampliaremos a otras figuras, en la caracterización inicial del patrón de Madrid seguimos encontrando elementos distintivos frente a otros ejemplos cristianos del XII.

En el siglo XIII se produce un rápido desarrollo espiritual e intelectual, con importantes cambios en los santos laicos, como por ejemplo que a partir de 1200 las mujeres comienzan a cobrar importancia (hasta ahora habían quedado excluidas, excepto algunas reinas). Así en el siglo xIII, con diferentes resultados en cada país europeo, se rehabilita la vida activa y se hace compatible con la santidad, ya no es necesario hacerse monje. Aunque la virginidad se sigue demandando para los servidores de Cristo, ni el trabajo, ni la vida familiar son considerados como obstáculos insalvables.

Más significativas para nuestro propósito son las similitudes de Isidro con los santos islámicos tardomedievales de la península y el norte de África. El modelo cristiano basado en la combinación del ascetismo y la contemplación, con el servicio a la humanidad, a través de la realización de milagros u otras habilidades supranormales, se corresponde con el del wali islámico ${ }^{35}$. Es fácil encontrar semejanzas entre las hagiografías de una

34 Pedro de RibADENEYRA, Flos Sanctorum de las vidas de los santos escrito por el padre........ de la compañia de Jesus, natural de Toledo aumentado con las de muchos por los PP. Jvan Eusebio Nieremberg, y Francisco Garcia, de la misma compañia de Iesvus. Y añadido vltimamente para todos los dias vacantes a las antecedentes impresiones por el muy R. P. F. Andres Lopez Guerrero del Orden de N S. Del Carmen, de la Observancia de la Provincia de Castilla. Tomo tercero. Contiene las vidas de los santos incluidas en los meses, de Setiembre, Octubre, Noviembre, y Diziembre (Barcelona: Joseph LLopis impresor, 1705), p. 310.

35 Richard KIECKHEFER and George D. BOND (eds.), Sainthood. Its Manifestations in World Religions (Berkeley-Los Angeles-London: University of California Press, 1988), p. 106. 
y otra religión. Hay prodigios que se repiten y narran de forma casi idéntica, además determinadas figuras (como San Vicente) fueron veneradas por ambas religiones en la Península ${ }^{36}$ al igual que ocurre con otros santos egipcios que reciben culto de musulmanes y coptos en sus tumbas, las cuales se sitúan en un edificio aislado de la iglesia o monasterio para que los seguidores de cada fe no se vean obligados a visitar el resto de las imágenes de la contraria ${ }^{37}$. No faltan estudiosos que atribuyen el desarrollo de la santidad islámica a la influencia del cristianismo, ya que inicialmente esta religión carece de ellos y su surgimiento es posterior. En la Península probablemente se produjeron influencias en los dos sentidos. Según Halima Ferhat y Hamid Triki ${ }^{38}$, como en el cristianismo, los primeros textos hagiográficos musulmanes se remontan a la tradición oral y suelen tratar de santos especializados en zonas determinadas. La obra de Tālidī Al-Mustafād contiene vidas marroquíes del siglo XII, destacando en ellas que, en oposición a los santos intelectuales andaluces, los bereberes suelen ser de escasa formación, aunque los hay de todas las categorías: esclavos, hombres de campo, analfabetos, dignatarios, artesanos, pecheros, marginados, etc. Para el conocimiento del tema en la Península contamos con la Epistola de la santidad ${ }^{39}$ de Ibn 'Arabī de Murcia, escrita en el 1203 y citada y reconocida como una de las principales aportaciones al sufismo islámico. Aunque la mayoría de los biografiados a uno y otro lado del Estrecho son grandes místicos y ascetas, vamos a resaltar aquí los paralelos encontrados con nuestro caso.

Como recordaremos, de Isidro, el autor del códice nos dijo que era "afable con sus semejantes". Este buen carácter es una cualidad frecuente en los santos musulmanes, gozó de ella, Aben Chueco, el toledano que habitó en Madrid, "ante cuyos hermanos y discípulos aparecía como el hombre más afectuoso y de mejor carácter, siempre con la sonrisa en los

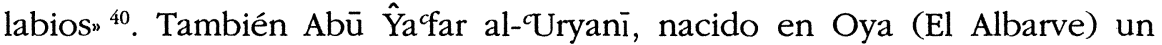
campesino analfabeto y casado ${ }^{41}$, "hombre de mucha meditación y lleno siempre de alegría en todos los estados de su trato espiritual con Diosn; y el zapatero Abū-l- ${ }^{c}$ Abbās Ahmad "Dulce de carácter, de excelente trato social y muy indulgente por temperamento" ${ }^{42}$.

36 Miguel José HaGerTy, Los cuervos de San Vicente, op. cit. , pp. 13-14.

37 Frederick M. DENNY, "Amigos de Dios: La santidad de las personas en el Islám", Richard KIECKHEFER and George D. BOND (eds.), op. cit., p. 83.

38 Halima FERHAT et Hamid TRIKI, op. cit., p. 18.

39 Miguel Asín PAlacios, Vidas de santones andaluces. La Epístola de la santidad de Ibn 'Arabi de Murcia (Madrid: Ediciones Hiperión, 1981).

40 Jaime Oliver Asín, 1951, op. cit., p. 286.

41 Miguel Asín Palacios, op. cit., pp. 52-62.

42 Miguel Asín Palacios, op. cit., p. 100. 
En su caracterización de los santos medievales marroquíes, Halima Ferhat y Hamid Triki ${ }^{43}$ afirman que éstos sienten repugnancia por el trabajo ajeno y consumen sólo lo que ellos producen. Aunque en el párrafo inicial reproducido, sólo se nos dice de Isidro que era un humilde labrador, más abajo, se aclara o añade que "eligió vivir no de manera distinta que ganando el sustento con el trabajo de su propias manos" ${ }^{44}$, palabras casi idénticas a las que Ibn 'Arabī escribe sobre varios santos andalusíes que conoció en Sevilla tales como: Abū-l-Haŷŷŷy, hombre de campo que "Vivía del trabajo de sus manos"; el fámulo Abū cAli al-Sakkāz, que "era hombre de energía, y se ganaba la vida con el trabajo de sus manos" o del zapatero sevillano Salih al-Jarraz que "se ganaba la vida con el trabajo de sus manos" ${ }^{45}$.

Esta cualidad es una nota distintiva de los santos islámicos, ya que, como dijimos, los cristianos de la época, casi en su totalidad se dedican a la vida contemplativa y ascética, rara vez ejerciendo una profesión. Incluso, cuando a partir de mediados del XII empiezan a aparecer laicos de clase media suelen terminar abandonando su trabajo para dedicarse por completo al servicio del prójimo y de Dios. Por el contrario, muchos de los musulmanes medievales ejercen profesiones humildes como campesinos o artesanos, pero como Isidro anteponen lo espiritual a lo temporal, abandonando o descuidando sus obligaciones para dedicarse a orar, mientras que Dios se ocupa de resolver sus necesidades. No vamos a añadir aquí ejemplos ni paralelos sobre este tema ya que lo trataremos más ampliamente al comentar el más renombrado de los milagros de San Isidro, en el que los bueyes aran sin ayuda humana.

Por último y muy brevemente queremos resaltar que el matrimonio y la formación de una familia no son obstáculos en el modelo de santidad islámica. Mientras que entre los cristianos, la mayoría de los laicos que llegan a santos hicieron votos de castidad o después de enviudar ingresaron en un convento, los musulmanes cuentan con numerosos ejemplos de casados y padres. De hecho la santidad se reivindica demostrando ser un descendiente directo de Mahoma y terminará por convertirse en una cualidad hereditaria, creándose verdaderos linajes a través de los siglos.

\section{MULTIPLICACIÓN DEL TRIGO TRAS ALIMENTAR A UNAS PALOMAS}

De modo que hasta tal punto estaba inflamado por la gracia de la caridad y ardía en amor divino, que alimentaba, según sus posibilidades, no sólo a los hombres,

43 Op. cit., pp. 42-45.

44 P. 116.

45 Miguel Asín Palacios, op. cit., pp. 79, 106 y 152 respectivamente. 
aunque no era rico, "como si nada tuviera y todo lo poseyera", sino también a las aves que padecían hambre y frío. $\mathrm{Y}$ así, sucedió que un día de invierno en que la nieve cubría la tierra, yendo a moler trigo en compañía de su pequeño hijo, vio una bandada de palomas posada en las ramas de los árboles y, percatándose de que corrían peligro de muerte por el hambre demasiado prolongada, compadeciéndose de ellas, apartó la nieve de la tierra con sus manos y sus pies, y echó abundancia del trigo que había aprestado para sus necesidades. Un acompañante suyo, al ver esto, se enojó y, en medio de mofas, juzgó al bienaventurado Isidro como a un necio por derrochar el trigo. Sin embargo, al llegar al molino no se halló en el saco de Isidro mengua alguna de trigo; al contrario, lo que es milagroso, hasta tal punto creció la harina, que los dos hombres llenaron a rebosar sus sacos, que antes estaban casi a la mitad ${ }^{46}$.

Las aves ocupan un lugar muy destacado en la mayoría de las religiones. Dios ama a los pájaros y se ocupa personalmente de su alimentación y supervivencia. Su hábitat en los cielos junto a Él, los coloca en una posición envidiable. Como los ángeles u otros seres próximos a la divinidad tienen la capacidad de volar y desplazarse rápidamente a cualquier lugar $\mathrm{y}$, con frecuencia sirven de mensajeros. Pero también viven y dependen de la naturaleza terrestre, suben y bajan constituyéndose en intermediarios entre el Cielo y la Tierra, entre Dios y los hombres. El propio Espíritu Santo adopta forma de paloma cuando baja a la tierra, al igual que las almas de los mártires caídos en la Guerra Santa (o, según autores, en forma de pájaros verdes), y la de más de algún cristiano, cuando asciende a los cielos. No es así raro que sus relaciones con los santos de ambas religiones haya sido tan estrecha.

Ya en el Génesis, Noé se sirvió de aves para saber si había bajado el nivel de las aguas y podía abandonar el arca: soltó primero a un cuervo que no regresó y después a una paloma que volvió con una ramita de olivo, señal de que ya se podía pisar la tierra. El cuervo y la paloma, dos especies muy comunes, ni pequeños pájaros, ni grandes rapaces son las que con más frecuencia se asocian a los santos. Las palomas, sin necesidad de prodigios milagrosos son beneficiosas para la cultura humana, que obtiene de ellas numerosos rendimientos en forma de alimentos, plumas, mensajería, incluso se emplean sus excrementos, palominos, como abono o materia prima en determinadas manufacturas. Pero los cuervos se consideran especialmente dañinos, sobre todo por sus ataques a los cultivos, consecuentemente, su sumisión y obediencia a un ser humano ha sido especialmente valorada en las sociedades agrarias.

Jose Luis Mingote ${ }^{47}$ se ocupó de un milagro de San Isidro, narrado

70 Pp. 115-116.

47 Luis Mingote Calderón, op. cit., 1993, pp. 135-153. 
por primera vez en las hagiografías del siglo XVI y XVII, muy similar al arriba reproducido, con las particularidades de que, el trigo es dado a pájaros en general, no palomas, además de a hormigas, y la ofrenda se produce durante la siembra. El autor apoyándose en el comentario introducido por Gregorio Argaiz (1671) y reproducido por Josep Nicolás de la Cruz (1715), de que tal vez se trate de una "costumbre antigua de los labradores virtuosos", relaciona el episodio con los ritos de protección del grano durante la siembra. Cita numerosos casos de ofrendas alimentarias a aves, ratones, ladrones e incluso a Dios (lo que indica la cristianización de la costumbre) ) como rito protector de los sembrados, procedentes de Tierra das Mariñas (La Coruña), donde se sembraba una porción específica de terreno para los pájaros, o se les echaba grano en las lindes del terreno, San Cugat del Vallés (Barcelona), y también documentables en otros países europeos como Francia, Alemania y Escandinavia. Nosotros podríamos ampliar el panorama con ejemplos norteafricanos como los recogidos por Emile Laoust ${ }^{48}$ entre los bereberes marroquíes que cuentan con ritos para expulsar a los yunn (genios o espíritus normalmente de carácter maléfico), los pequeños pájaros considerados como una encarnación de los malos espíritus y cualquier animal que pueda dañar los cultivos. Las ofrendas a las aves se realizan, unas veces en las lindes del terreno cultivado y otras, depositando un pan especial en una gruta. También se documentan los sacrificios expiatorios, consistentes en encerrar un pajarito en una jaula que se coloca en las lindes del sembrado y que luego es lapidado para que sirva de escarmiento a sus congéneres libres (Marruecos), o el matar un gallo o una gallina derramando su sangre por el sembrado (España). Asimismo Ángel Koller ${ }^{49}$ recogió cómo los bereberes piden limosna de granos de trigo, cebada y maíz que se colocan en un árbol sagrado cantando: "He aquí vuestro banquete, $;$ Oh yenun, oh espíritus y pequeños pájaros! iQue Dios bendiga nuestros campos!».

Pero sin menospreciar en absoluto el análisis de José Luis Mingote, no creemos que sirva para interpretar el milagro del que ahora nos ocupamos. En primer lugar porque, en nuestro caso, como el códice indica con toda claridad, la bandada de palomas no amenazaba ningún sembrado, ya que el episodio no sólo se produjo en invierno, sino que se especifica que el suelo estaba cubierto de nieve. Pero, sobre todo contamos con algunos ejemplos que muestran cómo los santos no necesitan recu-

48 Emile LaOust, Mot et choses berbéres. Dialectes du Maroc (Rabat, 1920), pp. 317, 339 y 342-344.

49 Ángel KOLLER, Los bereberes marroquies (estudio etnográfico) (Tetuán: Editorial Marroquí, 1952), p. 19. 
rrir a ritos para proteger los sembrados porque les basta su dominio o poder sobre aves y alimañas.

Ya en fechas muy tempranas (mediados del siglo II a C.) en el Libro de los Jubileos, apócrifo del Antiguo Testamento podemos encontrar al joven Abraham (tenía catorce años) que para proteger la sementera de las bandadas de cuervos que acudían a comérsela, les ordena: "No bajéis, volveos al sitio de donde salisteis", ahuyentando sólo con esta orden a setenta nubes de cuervos de todos los campos donde estuvo. Los que lo presenciaron vieron en ello un signo de su carisma y poder (en estas fechas todavía no se puede hablar de santidad) y "Fueron a él en este año todos los que sembraban, y los estuvo acompañando hasta terminar la sementera. Sembraron sus tierras, cosecharon aquel año alimento suficiente y comieron hasta hartarse " ${ }^{50}$. Veintidós siglos después y en el otro extremo del mundo mediterráneo, Antonio Cea recogió dos versiones de un romance cantado con un tema prácticamente idéntico ${ }^{51}$ : El padre de San Antonio, cuando éste era aún niño, le encarga ahuyentar a los pájaros que acuden al sembrado. Para ello el santo les ordena que se metan en una habitación. Cuando el padre regresa y ve el prodigio, convencido de que se trata de un milagro, avisa al obispo que, con todo su acompañamiento, presencia cómo las aves se someten al muchacho. También interesa resaltar el caso del andaluz San Diego ${ }^{52}$ que cultivaba un huerto con un compañero y cuando sorprendía a algún conejo destruyendo la hortaliza, le recriminaba y daba unos azotitos, pero dejándole en libertad.

De estas narraciones, tan distantes en el tiempo y el espacio, se podría inferir la creencia en que determinadas personas elegidas por Dios manifiestan su status, ya desde su juventud, gracias al poder de ahuyentar las aves y depredadores de los sembrados, simplemente con ordenárselo.

Característica muy acentuada de los santos medievales es presentarse

50 Citado por Mariano GÓMEz ARANDA, "Transmisión oral y trasmisión escrita: La Biblia hebrea", Luis Díaz G. VIANA y Matilde FERNÁNDEZ MONTES (eds.), Entre la palabra y el texto. Problemas en la interpretación de fuentes orales y escritas (MadridOiartzun: Sendoa, 1997), pp. 259-260.

51 San Antonio y los pajaritos, versiones de Miranda del Castañar, recogidas por Antonio Cea en 1974 y 1983.

52 Alonso de Villegas, Flos sanctorum vida, y bechos de Jesu-Christo, Dios, y Señor nuestro, y de todos los santos de que reza la iglesia catbolica. Conforme al breviario romano, reformado por Decreto del Santo concilio Tridentino. Junto con las Vidas de los Santos Proprios (sic) de España. por el M......., capellan de la capilla Mozarabe de la Santa Iglesia de Toledo. En esta ultima impresion se han coordenado en un solo cuerpo por su mes, y dia proprio todos los Santos, y algunos otros. (Barcelona: por la Viuda Piferrer, 6-XII-1787) (1ª ed, 1775), p. 756. 
como señores de la naturaleza, con capacidad de dominar y controlar las fieras y otros animales, especialmente las pájaros que unas veces les obedecen, y otras les protegen o prestan determinados servicios. Las aves, especialmente las carroñeras asumen la defensa de los cuerpos de los mártires cuando éstos son abandonados a la intemperie para evitar la destrucción de las reliquias. Así, en el siglo iv, cuando San Vicente ${ }^{53}$ fue martirizado en Valencia, Daciano encargó que su cadáver fuera arrojado a un cenagal para que las alimañas se lo comieran, pero un cuervo se encargó de custodiarlo enfrentándose y ahuyentando incluso a un lobo. Los cuervos se asociaron al santo patrón de Al-Andalus y su comunidades mozárabes, de tal manera que también lo acompañaron durante su traslado al Algarve (cabo de San Vicente) en el siglo viII. Allí permanecieron revoloteando sobre el monasterio-mezquita, alejándose solamente para contar los peregrinos musulmanes y cristianos que acudían y que los monjes tuviesen suficiente comida preparada ${ }^{54}$. De la misma manera, las águilas hicieron guardia ante los cuerpos de San Vito y San Modesto hasta que una mujer se hizo cargo de ellos y los sepultó piadosamente ${ }^{55}$.

Por otra parte, también casi desde los primeros momentos del cristianismo, muchos eremitas que abandonaron la vida social y sus recursos para instalarse en alejadas cuevas campestres contaron con el apoyo de algún pájaro que les proporcionaba alimento. Como San Pablo, el primer ermitaño († 287), al que un cuervo traía todos los días una porción de pan, doblando la ración cuando fue a visitarle San Antonio ${ }^{56}$. Una mayor reciprocidad tenían las relaciones de San Blas, obispo de Sebaste (Capadocia), a quien, cuando vivió como un ermitaño, infinidad de pájaros de diversas especies acudían a visitarle, le llevaban comida y no se alejaban de su lado, hasta que él, tras acariciarlos, les bendecía. Cuando alguna de aquellas aves se sentía indispuesta iba en busca de alivio a la cueva del santo varón y enseguida se recuperaba ${ }^{57}$. Mientras, San Benito que alimentaba a un cuervo con su propias manos, cuando por envidia le dan un pan envenenado, se lo entrega al animal para que lo arroje lejos, el cuervo regresa a los tres días y recibe su ración acostumbrada.

53 Alonso de Villegas, op. cit., p. 140.

54 M. J. HAGERTY, op. cit., pp. 12-13.

55 Santiago de la Vorágine, La leyenda dorada (Madrid: Alianza Forma, 1982), p. 330 .

56 Santiago de la Vorágine, op. cit., p. 98 y Alonso de Villegas, op. cit., pp. 177 (San Pablo) y 118-119 (San Antonio).

57 Santiago de la Vorágine, op. cit., p. 164. 
El mismo, tres días después de ingresar en un monasterio vio cómo el alma de su hermana, en forma de paloma surcaba el espacio y entraba en el cielo ${ }^{58}$. O San Columbano que, cuando un cuervo le robó los dediles con los que se protegía la mano mientras segaba, le dijo que no daría de comer a sus polluelos hasta que le devolviera la manopla, lo cual hizo inmediatamente, aguardando a sus pies el merecido castigo que el santo naturalmente le perdonó 59 .

Otras veces los pájaros entran en contacto físico con los santos, demostrando así su mansedumbre, como le sucedía a San Remigio a quien se le posaban sobre su mesa y tomaban de sus propias manos las migajas que quedaban en los manteles ${ }^{60}$. A San Segundo durante un viaje en compañía del perfecto de Asia, una paloma se le posó sobre la cabeza. «El perfecto al ver aquello entre sorprendido e irónico dijo a su acompañante: Segundo, nuestros dioses te quieren tanto que hasta envían aves del cielo a visitarte" ${ }^{61}$. Aunque sin duda el ejemplo más emblemático y difundido es el de San Francisco de Asís, al que se suele representar con los brazos extendidos con multitud de pájaros sobre ellos.

Pero en el relato del milagro de las palomas, seguimos encontrando singularidades. No se parte de una relación continua o amistosa entre Isidro y determinadas especies o ejemplares en concreto, como es norma en los casos antes citados, sino que se trata de algo puntual y esporádico. También es cierto que otros santos cristianos las han alimentado, pero ninguno de ellos ofrece lo que tenía reservado para sus propias necesidades y las de su familia incluyendo un hijo pequeño, al que su propio padre "le quita el pan de la bocan. Los motivos de este comportamiento son como el propio códice señala, su extremada generosidad y la sensación que tuvo de que las palomas tenían hambre y estaban en peligro de muerte.

Halima Ferhat y Hamid Triki ${ }^{62}$ destacan la estrecha relación de los santos musulmanes con la naturaleza; forman parte del entorno y son capaces de controlar los fenómenos naturales y las bestias salvajes. Además sienten un gran respeto por la vida animal y vegetal, encargándose de mantener los equilibrios ecológicos. El comportamiento de Isidro bien podría encajar en esta línea que además le acerca o asemeja al propio Allah, que es quien se ocupa de alimentar y mantener a todas las criatu-

58 Ibid., pp. 203-207.

59 Pedro de Ribadeneyra, op. cit., vol. III, p. 370.

60 Santiago de la Vorágine, op. cit., p. 99.

61 Ibid., 236.

62 Halima FERHAT y Hamid TrikI, op. cit., p. 44. 
ras, como lo demostró ante Dzou'1 Noun el egipciano ${ }^{63}(† 795)$, cuya conversión al misticismo se produjo cuando se puso a dormir bajo un árbol y vio caer de su nido a un pequeño pajarito con los ojos todavía cerrados. Para alimentar al infortunado salieron del suelo dos copas, una de oro llena de granos de sésamo y otra de plata con agua fresca.

La generosidad desmesurada de nuestro santo se ve recompensada con un acto de reciprocidad. El abundante trigo echado a las palomas, no sólo no produce una merma en la cantidad restante, sino que incluso, después de la molienda crece aún más, colmando su saco y el de su compañero.

Podríamos pensar que Dios realiza este milagro para recompensar su actuación, pero también, basándonos en algunas creencias, se podría añadir que aquellas palomas eran algo más que simples pájaros. Un santo medieval marroquí, nos da la clave: Abu I-Hasan l-Shadhili (593/1196-656/ 1258) caminaba en compañía de un discípulo, cuando un estado irresistible se apoderó de él y le arrastró fuera del camino. El discípulo vio cuatro aves parecidas a cigüeñas bajar del cielo, alinearse por encima de su cabeza, hablar con él, una a una y luego remontar el vuelo. A continuación una bandada de pájaros desde la tierra hasta el cielo le rodea y luego desaparece. Cuando el jeque volvió al camino, le explicó a su acompañante que los pájaros grandes eran ángeles del cuarto cielo que le habían preguntado acerca de determinadas ciencias. En cuanto a los pequeños eran los espíritus de los santos que habían acudido a recibir su bendición ${ }^{64}$. En efecto, según creencias y supersticiones documentadas entre los musulmanes norteafricanos por Westermarck ${ }^{65}$, ciertas especies de aves están dotadas de santidad como la cigüeña, la abubilla, la tórtola, la paloma doméstica, etc. Koller ${ }^{66}$ califica a grutas, higueras, alcornoques, algarrobos, olivos, reptiles, pájaros, serpientes, salamandras, cigüeñas y golondrinas como portadores de baraka y gracias superiores, se les da también el nombre de agurram $^{67}, \mathrm{y}$, al parecer son considerados como ídolos

${ }^{63}$ Emile Dermenghem, Vies des Saints Musulmans (Provence: Edition d'Aujourd'Hui, Colletion "Les introuvables", 1981), p. 107.

64 Denis GRIL, "Un santo fundador", Alexandre POPOVIC y Gilles VEINSTEIN (coords.), Las sendas de Allah. Las cofradias musulmanas desde sus origenes hasta la actualidad (Barcelona: edicions Bellaterra, Biblioteca del Islam Contemporáneo, Serie Ibn Jaldún), p. 137. En los santos musulmanes las cifras separadas por una barra corresponden, la primera, al año de la hégira y la segunda, a la era cristiana.

65 Edward WestermarC, Pagan survivals in mohammedan civilisation (Amsterdam: Philo Press, 1973), pp. 107-108 (1르 ed. 1933).

${ }_{66}$ Ángel Koller, op. cit., p. 165.

67 El agurram es un santo iletrado bereber, dedicado a la oración y el sacrificio, que practica unas costumbres religiosas muy tradicionales. 
populares en los cuales se encarna el poder secreto de las cosas: el alma del mundo. La función agorera de las aves también está aquí documentada considerándose de buen agüero la golondrina, la cigüeña y la paloma ${ }^{68}$, mientras que el buho y el cuervo lo son de malo. A las golondrinas, conocidas como "golondrinas del profetan se las debe respetar y cuidar si se las encuentra heridas, acarreando la desgracia al que destruya su nido. También se respeta al picabuey, del que se cree que es un estudiante encantado, tras realizar un hechizo sin éxito, mientras que la tórtola era un sabio que se dedicaba a la función del almuédano y por eso dice constantemente: Decru Al-lab (Alabad a Dios).

En esta línea es posible que Isidro creyera que las palomas posadas en los árboles (también con carácter sagrado en el Islam) fueran aves de Dios, encarnación de almas o espíritus de santos, animales benéficos a los que hay que proteger y cuidar para obtener su influencia beneficiosa. Lo cierto es que su compañero no comprendió su proceder y se burló tachándolo de necio, a pesar de lo cual también obtuvo una parte de la multiplicación milagrosa de la harina tras la molienda. Este último incidente puede interpretarse de dos maneras, la primera es que los dos personajes no compartían las mismas creencias por pertenecer a tradiciones culturales distintas, ya fueran cristianos, judíos o moros. El espíritu conciliador e integrador entre varias culturas que se puede observar en el códice, no provoca una represalia por las burlas, como hubiera sido lo normal, ya que en esta época, tanto entre los cristianos, como entre los musulmanes abundan los "milagros-castigos", sino que, por el contrario, también él es recompensado, pudiendo comprobar así el carisma de Isidro y la superioridad de sus prácticas y creencias.

Pero probablemente y como en otros prodigios podremos comprobar, tal vez se trate de algo inherente al modelo de santidad islámico, que con frecuencia se reconoce en locos, necios y seres marginales, con unas actuaciones extravagantes o incomprensibles. Muchas veces se ha dicho que el género hagiográfico tiene como principal fin crear pautas o modelos de conducta para los oyentes, pero tras la lectura de múltiples hagiografías medievales de ambas religiones, nos atrevemos a afirmar que en la mayoría de los casos esto no es así en ninguna de las dos. Los santos unas veces por su origen, otras por sus actuaciones, se presentan como seres anormales y asociales, siempre dispuestos a romper y enfrentarse con las normas de su lugar y momento. Pero además, los auténticos se caracterizan por su humildad, huyen de la vanagloria y tratan de silen-

68 Mohammad IBN AZZUZ AKÍM, Diccionario de supersticiones y mitos marroquies (Madrid: CSIC, 1985), p. 13 y bajo los nombres de cada ave mencionada. 
ciar sus milagros, como del propio Isidro se nos dice tras dos multiplicaciones de alimentos. Esta actitud en el mundo islámico dio origen en el siglo $\mathrm{x}$ a un tipo de santos denominados malāmatī, que tenían una actitud ascética consistente en no hacer ningún tipo de ostentación de la virtud, llegando a adoptar comportamientos socialmente censurables, con objeto de evitar los peligros de la vanidad y el reconocimiento de los demás. Existían también los llamados bahlūl que, además de bufón o gracioso, significa tonto o inocente, aludiendo al simple de espíritu dotado de una sabiduría especial ${ }^{69}$. Lo anormal y disparatado que provoca las críticas y recelos de sus conciudadanos, como reiteradamente le sucederá a Isidro es paradójicamente un signo de santidad.

Por último y en defensa de nuestro personaje queremos añadir que, aunque efectivamente no hay ningún santo, ni cristiano ni musulmán, anterior o contemporáneo que dedique parte de sus recursos a alimentar bandadas de palomas, su proceder inauguró una tradición. Hasta tal punto que la especie se han habituado a la vida urbana y son muchísimas las ciudades europeas donde conviven en simbiosis con el hombre. Junto a las principales plazas e iglesias, se pueden ver vendedores de su comida que los turistas y ciudadanos adquieren por el único placer de ver cómo estas mansas aves de carácter sagrado, que han llegado a constituirse en un símbolo de la paz acuden a comer de sus propias manos.

\section{DOS YUNTAS DE BUEYES ARAN SOLAS JUNTO A ISIDRO}

2. En modo alguno merece ser silenciado el segundo y principal milagro que, entre otros, la divina Providencia se dignó realizar, valiéndose de Isidro, el siervo de Dios.

[...] se convirtió en humilde arrendatario de un caballero de Madrid a cambio de un sueldo anual. Así que, en esta condición de alquilado, establecido en el campo cerca de la Villa, pasaba la vida trabajando en compañía de su mujer y daba a Dios lo que era de Dios y a los vecinos la debida fraternidad. Pero algunos de éstos se presentaron al caballero, cuya propiedad trabajaba Isidro por la paga conocida, y lo acusaron en los siguientes términos: "Venerable señor, nosotros, como conocidos y subordinados tuyos, confesamos que esta es la verdad: [...] Sabed, con toda seguridad, que aquel dicho señor Isidro, a quien elegisteis para trabajar vuestra posesión en el campo por un sueldo anual, levantándose muy de madrugada y después de abandonar el ineludible trabajo del campo para ausentarse, se va a visitar todas las iglesias de Madrid, so pretexto de orar en ellas. Así, puesto que ya avanzado el día vuelve muy tarde al trabajo, no cumple ni siquiera

69 Fernando Rodríguez MEDiANO, "Santos arrebatados: algunos ejemplos de maŷdūb en la Salwat al-anfās de Muhammad al-Kattān̄̄", Al-Qantara. Revista de Estudios Árabes, XIII, (1992), p. 234. 
con la mitad de la faena establecida. Por lo demás, no nos tengáis por malévolos o envidiosos al haberos expuesto lo que era útil y provechoso para vuestra casa." Después de oír esto, el propietario se desconcertó y, personándose al día siguiente, se irritó al comprobar que era cierto lo que se le había denunciado y acercándose al santo varón le reprendió con dureza. Pero el bendito Isidro, ya aleccionado en la paciencia cristiana, respondió con estas sencillas palabras "Queridísimo y venerado señor, a cuyo patrocinio me he sometido, sinceramente os manifiesto que no quiero ni puedo en modo alguno separarme del Rey de reyes ni de la grey de los Santos ni de su servicio. Mas, si teméis que por demorarme en comenzar mi trabajo, disminuya la riqueza debida en los frutos de las cosechas, estoy dispuesto a restituir por completo la merma denunciada por los vecinos. Por ello, os suplico por vuestra bondad que en modo alguno toméis a mal que cumpla con mi deber como siervo del Señor, sin perjudicar vuestro interés".

Oídas estas palabras, el honrado caballero volvió a su casa con la concesión de esta modesta gracia, mas un tanto dudoso sobre lo que había escuchado. [...] Isidro [...] se empeñó en no dejar su costumbre de visitar con asiduidad las iglesias de Dios para rezar, [...]

Pero el susodicho patrono, a cuyas órdenes estaba Isidro, planeando comprobar lo que hacía el hombre de Dios, un día se levantó muy temprano y poniéndose en camino, se escondió al abrigo de una cueva para ver con sus propios ojos lo que hacía. Y como hubiese comprobado que el siervo de Dios volvía demasiado tarde de su recorrido habitual y juzgase que aplicaba su mano en el arado de una forma, por decirlo así, negligente, se afligió ante la evidencia. Por lo que, alterado, salió para recriminarle duramente por esto. [...] mientras el citado caballero se dirigía irritado contra el servidor de Dios, vio de repente en el mismo campo, por designio del poder divino, realizando el trabajo de labranza, que dos yugadas de bueyes de color blanco, que araban al lado del siervo de Dios y sin propietario, labraban el campo rápida y resueltamente.

Advertido y asombrado por esa visión, se detuvo en su avance lleno de estupefacción y pensando con desconcierto qué era esto. Pero, sabiendo de antemano que Isidro no tenía ninguna ayuda humana, casi a la fuerza tuvo que creer que al varón de Dios no le faltaba auxilio divino. Así, pues, mientras que con gozo y admiración se aproximaba a indagar y enterarse de cerca de qué se trataba, volviendo un instante los ojos a otra parte y dirigiéndolos de nuevo al cultivo del campo, no vio labrar a otro más que al servidor de Dios, Isidro; mientras le daba muchas vueltas en su corazón a aquel prodigio, finalmente llegó a entender su significado y, después de saludar, el patrono, con mucha discreción, le hizo al siervo de Dios, Isidro, la siguiente pregunta: "Te ruego, por Dios, a quien tú fielmente sirves, que me dejes ver a los ayudantes que te acompañaban poco antes en tu trabajo del campo. Pues yo vi contigo a algunos otros que te ayudaban a labrar, pero se han desvanecido repentinamente de mi vista en un abrir y cerrar de ojos". Entonces el justo varón de Dios, muy consciente, respondió con esta sencillez: "En presencia de Dios, a quien sirvo según mis posibilidades, os manifiesto honestamente que en esta labranza ni he llamado ni he visto ayudantes algunos, excepto a Dios, a quien invoco e imploro y siempre lo tengo como ayuda". Entonces el propietario, impresionado en su corazón por estas cosas que había visto e iluminado por el cielo, comprendió que la gracia divina residía en el siervo de Dios. Y así, inmediatamente antes de marcharse del campo, le dijo: "Des- 
precio todo lo que me dijeron los aduladores o chismosos; desde ahora, pues todo lo que poseo en este campo, lo dejo bajo tu poder y también todo lo que sea necesario hacer, lo dejo a tu libre decisión". [...] ${ }^{70}$

Este milagro, que ya en el siglo XIII se consideraba, como hoy, el principal y más difundido, rompe en varios aspectos la estructura del primer sector que comentamos. La amplitud del relato dobla con creces a la del resto y además vuelve a incluirse, a su inicio, una breve caracterización biográfica, mencionándose que trabajaba como arrendatario o siervo de un caballero madrileño, que estaba felizmente casado y que vivía en el campo a las afueras de la villa. Su composición consta de una presentación del protagonista, seguida del planteamiento de la trama, desarrollo del conflicto y feliz desenlace. Lo que parece indicar que fue concebido como una pieza independiente, en la que no sólo se introducen los diálogos, sino que también se emplean otros recursos teatrales, como el énfasis en las descripciones de sentimientos y actuaciones, o la detallada descripción de los movimientos y posiciones de los personajes: Con vivos adjetivos se opone la irritación e impaciencia del caballero, a la humilde mansedumbre de Isidro, al igual que la súbita transformación de los sentimientos del primero al comprender el prodigio:

\begin{tabular}{|c|c|}
\hline Amo & Isidro \\
\hline se desconcertó... se irritó & paciencia cristiana \\
\hline le reprendió con dureza & $\begin{array}{l}\text { sencillas palabras } \\
\text { no lo toméis a mal }\end{array}$ \\
\hline $\begin{array}{l}\text { dudoso de lo que había escuchado } \\
\text { se escondió al abrigo de una cueva }\end{array}$ & $\begin{array}{l}\text { inamovible ante las acometidas de } \\
\text { preocupaciones y amenazas persiste } \\
\text { en su costumbre }\end{array}$ \\
\hline $\begin{array}{c}\text { se afligió } \\
\text { alterado salió para recriminarle } \\
\text { duramente } \\
\text { se dirige irritado }\end{array}$ & $\begin{array}{l}\text { vuelve demasiado tarde } \\
\text { labra negligentemente }\end{array}$ \\
\hline \multicolumn{2}{|l|}{$\begin{array}{l}\text { Advertido y asombrado se detiene } \\
\text { lleno de estupefacción y pensando } \\
\text { con desconcierto }\end{array}$} \\
\hline $\begin{array}{l}\text { con gozo y admiración se acerca a } \\
\text { indagar y a enterarse } \\
\text { le da muchas vueltas en su corazón } \\
\text { saluda con mucha discreción y } \\
\text { pregunta }\end{array}$ & $\begin{array}{c}\text { muy consciente responde con sencillez } \\
\text { honestamente manifiesta que sólo } \\
\text { Dios le ayuda } \\
\text { no ha visto ni ha llamado } \\
\text { a ayudante alguno }\end{array}$ \\
\hline $\begin{array}{l}\text { impresionado en su corazón e } \\
\text { iluminado por el cielo comprende } \\
\text { desprecia a aduladores y chismosos } \\
\text { se despide y cuenta a muchos lo } \\
\text { sucedido }\end{array}$ & \\
\hline
\end{tabular}

70 Pp. 116-118. 
El relato, más que la narración de un milagro, se podría clasificar como la exposición de un conflicto social entre caballeros y siervos medievales, pues el enfrentamiento entre la conducta de Isidro y los intereses del amo al que cultiva sus tierras es la trama principal. Los siervos, como lo fue nuestro santo estaban prácticamente excluidos en la época del acceso a la santidad, entre otras cosas porque sus necesarias prácticas religiosas inevitablemente supondrían una merma o detrimento del tiempo dedicado a trabajar. Hasta ahora los santos laicos medievales suelen ser nobles y ricos que donan su fortuna a los pobres e ingresan o fundan monasterios y hospitales, o se hacen eremitas, pero su vida contemplativa y espiritual, despreciando el trabajo material, no se concibe como un modelo de conducta extensible a los plebeyos y aún menos a los vasallos. Aunque ya en el siglo XII aparecen santos de origen humilde que terminarán como frailes menores ${ }^{71}$, realizando las necesarias labores serviles en la congregación (la falta de cultura y dinero para la dote excluyen el ingreso en la orden monástica a pie de igualdad), el proceder de Isidro en este caso, no tiene precedente alguno en la hagiografía cristiana. Así, de San Simeón Stilita ${ }^{72}$ procedente de Asia Menor, que ejerció como pastor cuando era niño, nos dice el Flos Sanctorum, que una vez que fue a la iglesia a escuchar los evangelios dejó antes el ganado en sitio bien seguro y abrigado. Todavía más explícita es la conducta de San Maco, un hijo de labradores nacido en Antioquía, pastor y siervo que siempre estaba mirando por la hacienda de su amo siguiendo el dictado: "que los esclavos sirvan a sus amos como a Dios" ${ }^{73}$. Mientras que, más cercano en el espacio y en el tiempo, San Millán ${ }^{74}$ († 904) también pastor de ovejas durante su infancia y juventud, se dedicaba a rezar tan sólo cuando había acabado su trabajo, mientras sus compañeros se iban de fiesta o se dedicaban a cantar y tocar el rabel. Habrá que esperar a que Madrid se convierta en la sede de la corte y comience a divulgarse la hagiografía del patrón, iniciándose los trámites para el proceso de canonización, a finales del XvI, para que aparezcan otros con conductas similares, aunque nunca mostrarán una desobediencia y un enfrentamiento tan abierto como en el relato del códice. Nos referimos por ejemplo, al italiano Felix de Cantalicio ${ }^{75}$ que antes de meterse a monje capuchino fue un siervo labra-

71 André VAUCHEZ, La espiritualidad del occidente medieval (siglos VIII-XII) (Madrid: Ediciones Cátedra, 1985), pp. 115-116.

72 Alonso de Villegas, op. cit., p. 98.

73 Pedro de Ribadeneyra, op. cit., vol III, p. 225

74 Alonso de Villegas, op. cit., p. 759.

75 Pedro de Ribadeneyra, op. cit., vol. II, pp. 106-107. 
dor; normalmente rezaba en los ratos libres y por la noche, dándose también el caso de que se le veía en la iglesia y labrando el campo a la vez. Según hagiografías españolas más recientes, en una ocasión, un ángel le sustituyó en la labranza mientras él iba a la iglesia ${ }^{76}$. También el catalán, beato Miguel de los Santos († 1591) trabajaba en la tienda de paños de sus tíos, descuidando sus obligaciones para orar, lo que le valía frecuentes palizas con la vara de medir. Pero se trata ya de figuras del XVI cuando el surgimiento urbano ha terminado por liquidar los vestigios de la mentalidad feudal medieval y se ha impuesto un nuevo modelo de espiritualidad y santidad.

En contrapartida, dentro de la hagiografía musulmana medieval es fácil encontrar ejemplos similares como el de Abū Ŷa cfar al.'Urgarī, un campesino iletrado al que cuando dejó de trabajar para dedicarse al trato con Dios, su mujer comenzó a gritar e injuriar diciendo: "iLevántate de ahí y trabaja y trae a casa lo necesario para mantener a tus hijos durante este año! ${ }^{77}$. El santo pide a Dios que le libre de la preocupación de su mujer $\mathrm{y}$, al poco rato, aparece un hombre en la puerta de su casa con un costal lleno de higos, al que se fueron sumando otros diez y nueve (antes se había mencionado que con ocho alimentaba a su familia durante un

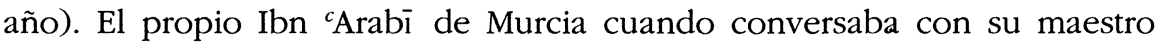
espiritual Yūsuf al-Kūmī ${ }^{78}$, pretendió irse para resolver cuatro asuntos urgentes, a lo que éste replicó: «i me dejas y te marchas, no lograrás ultimar ni uno solo de esos asuntos. [...] Yo te garantizo la resolución de esos asuntos", como efectivamente sucedió y pudo comprobar al llegar a su casa. Por último, citaremos el caso extremo del andaluz Abū 'Abd Allāb Muhammad b. Qassūm ${ }^{79}$, quien se ganaba la vida cosiendo gorros; un día que se le había acabado el dinero, cuando se disponía a trabajar oyó un ruido en la puerta y, al acercarse vio que habían echado allí seis dinares. Ante esto optó por tirar sus herramientas diciendo: “Si Dios provee a mi sustento, voy yo a preocuparme de buscarlo ni a tomarme el trabajo de procurarme una cosa de la cual Dios mismo me sale garante", abandonando su oficio y viviendo a partir de entonces de la limosna.

Pero los paralelos con el modelo de santidad islámico se pueden llevar todavía más lejos. La conducta de Isidro descuidando su trabajo para dedicarse a la oración, no supone una amenaza para el mantenimiento

${ }^{76}$ Edelvives, El santo de cada día. III mayo-junio (Zaragoza: Ed. Luis Vives, 1954), p. 182.

77 Miguel Asín Palacios, op. cit., p. 58-59.

78 Ibid., pp. 69-70.

$79 \quad$ Ibid., p. 87. 
de su familia, sino que el detrimento repercute en su amo, quien le reprende y amonesta, a pesar de lo cual él mantiene sus piadosas costumbres. La oposición a los abusos de poder y sus diferentes autoridades y representantes es otra de las características señaladas en los santos marroquíes ${ }^{80}$ que, con su actuación pretenden restablecer la justicia. Las prácticas religiosas, con independencia del tipo de creencias, forzosamente requieren una dedicación temporal que, en caso de siervos medievales, se resta del servicio al señor. No olvidemos que el relato no se desarrolla en el centro urbano de Madrid, sino a las afueras, en un campo de carácter feudal, donde verdaderamente vivió nuestro santo, el cual, para rezar acudía a la villa en la que se encontraban las iglesias y era posible desarrollar un tipo de religiosidad, de la que en la práctica estaban excluidos los campesinos, por ser incompatible con las exigencias de su trabajo y, sobre todo, en caso de vasallos, con las de sus amos.

Por otra parte, de nuevo en este milagro encontramos el carácter marginal y antisocial que comparte con otros santos marroquíes. Si en el anterior relato el compañero de Isidro se burla de él y le trata de necio, en éste, aunque al inicio se especifíca que observaba la debida fraterni$\mathrm{dad}$, son sus propios vecinos quienes le denuncian ante el caballero, no sin cubrirse las espaldas ante una posible reacción adversa, advirtiendo que no se les considere por ello malévolos o envidiosos, sino que actúan en beneficio de su hacienda. El final feliz incluye el desprecio del amo a los aduladores y chismosos que a partir de este momento quedarán en un plano de inferioridad ante nuestro santo, el cual es ascendido en sus responsabilidades, dejándosele libre albedrío para organizar y tomar las decisiones que considere oportunas.

Por último, queremos detenernos en un aspecto fundamental que ha sido alterado en versiones posteriores, mucho más difundidas que la presente. Nos referimos al hecho de que el amo no ve, como tantas veces se ha dicho, a dos pares de yuntas de bueyes blancos guiadas por ángeles, sino que éstas labran solas, sin que ningún ser visible las guíe o conduzca. La variante fue introducida en el propio códice, aunque no en el relato de los milagros, la parte más antigua que, como ya hemos dicho, teóricamente se sitúa a finales del XI y gran parte del XII, sino en los oficios que se cantaban en la iglesia de San Andrés en honor del santo; así en el Himno I se puede leer:

80 Halima Ferhat et Hamid Triki, op. cit., p. 42. Véase también entre otros, Francisco RODRíguez MAÑas, "Hombres santos y recaudadores de impuestos en el occidente musulmán: siglos VI-VIII-XII-XIV", Al Qantara, XX, (1991). 
Unce los bueyes al arado para labrar el campo y la diestra divina alivia la aguijada del duro trabajo. Acuden bueyes que, guiados por un ángel hacen surcos en la otra parte. [...] El amo [...] Pues había visto que araba en el campo con bueyes blancos un joven, al que había tomado por un vecino que le ayudaba. Pero cuando hizo acto de presencia, no vio a nadie ${ }^{81}$.

El especialista en agricultura tradicional, José Luis Mingote que como en el caso del milagro anterior es el único antropólogo que ha analizado el relato original y las variantes posteriores ${ }^{82}$, hace un recuento de toda una serie de personajes de la mitología popular que colaboran en las tareas agrícolas. Comenzando con las lamias que compara con los lares por sus funciones protectoras de los campos y las casas, a las cuales en el País Vasco-francés, se les deja comida por la noche en la casa y a la mañana siguiente aparecen los campos labrados (según las versiones recogidas por Barandiarán en Bazterrechea y Gaztelu, las ofrendas alimentarias se colocan en las lindes de los campos). Asimismo los gentiles de Autaún y los familiares de los Pirineos ayudan a los vecinos en sus labranzas, al igual que lo hacen frecuentemente las hadas que también colaboran hilando y el Nublao (espíritu de León) o Nuberu (Asturias) que, si se le dan atenciones ofrece buenas cosechas. Mingote, en su análisis de estas creencias populares advierte cómo la actuación de los ángeles con San Isidro se equipara pero a la vez se opone a la de las lamias vascas, comparando las oraciones del primero, a las ofrendas alimentarias para las segundas.

Pero, por más que la versión de los ángeles se haya impuesto en la literatura y la iconografía hagiográfica, lo cierto es que a Isidro, según el relato más antiguo del códice, en realidad le ayudaban unos seres invisibles y, de nuevo como en el caso anterior, las creencias y supersticiones norteafricanas sobre seres míticos resultan altamente significativas. Nos referimos a los yunn (plural de yinn), espíritus marroquíes asimilables en parte a los familiares, espíritus y trasgos de la mitología del norte español, que pueden aparecerse en forma de personas, de seres alados, o de reptiles u otros animales, aunque lo más frecuente es que sean invisibles; se les oye, se ve lo que hacen, o se percibe su presencia por algo extraño pero no se ven. Los yunn pueden ser masculinos o femeninos, de carácter maligno o benigno. Los malos atacan a hombres, animales y cultivos y se pueden evitar ofreciéndoles sacrificios y ofrendas de comida que se dejan en las lindes de los campos para que se porten bien, de forma muy similar a como se procede con lamias, familiares y espíritus.

81 Pp. 134.

82 José Luis Mingote, op. cit., 1992. 
Algunos de ellos se convirtieron en ángeles y según Westermarck ${ }^{83}$ los santos islámicos difuntos, para realizar su milagros son ayudados por yunn a modo de sirvientes regulares, lo que encajaría bastante bien con el relato que nos ocupa. Mohammad Ibn Azzuz Akím añade que también pueden dar una buena cosecha ${ }^{84}$.

El bienaventurado Isidro, cuando el caballero le pregunta quién le asistía en la faena, no da ningún tipo de contestación convincente, sino que por el contrario niega la existencia de ayudantes. Este proceder tratando de silenciar los milagros, que, como se verá, repite en algún otro episodio es fruto de su infinita humildad, cualidad que comparte tanto con sus homólogos cristianos, como con los islámicos. Curiosamente es tras esta negación cuando el amo comprende que su asalariado es algo más que un simple campesino; que "gracia divina residía en el siervo de Dios". Si tuviésemos que traducir al árabe esta expresión la palabra más adecuada sería baraka, cualidad que poseen no sólo los santos, sino toda una serie de seres animados e inanimados con un poder benéfico de origen sagrado.

\section{ISIDRO NO ABANDONA LA IGLESIA PARA PROTEGER A SU ASNO}

3. Un día de fiesta de verano, aconteció que el hombre de Dios, según su costumbre, entró pasado el mediodía en la iglesia de Santa María Magdalena a consagrar sus rezos a Dios. Y mientras persistía devotamente en la oración, se presentaron unos jóvenes, quienes a toda prisa le comunicaban la siguiente noticia: "Levantaos, padre Isidro, y acudid lo más rápidamente posible, porque un lobo voraz persigue a vuestro burro y lo acosa antes de herirlo de muerte. Entonces el varón de Dios les contestó: "Id en paz hijos; hágase la voluntad del Señor". Y una vez acabada la oración, salió a ver qué había ocurrido con el peligro avisado y encontró a su asno libre y sin heridas. Por esta razón, reconfortado por la Divinidad, volvió al punto a la iglesia de Santa María Magdalena para dar gracias a Dios, cuya misericordia "socorre a los hombres y a las bestias" ${ }^{85}$.

Este milagro es en buena parte comparable al anterior y muchos de los comentarios y paralelos señalados son igualmente válidos; Isidro antepone lo espiritual a lo temporal y Dios recompensa su proceder solucionando o solventando el problema que demandaba su atención inmediata. Pero las diferencias son también notables, si el de los bueyes que aran solos, ya a finales del xill era uno de los prodigios más renombrados,

83 Op. cit., p. 5 y ss. (1." ed. 1933).

84 Op. cit., p. 54.

85 Pp. 118. 
llegando a caracterizar al santo y por tanto mereció un amplio relato, este brevísimo episodio no sólo ha pasado prácticamente desapercibido, sino que además contiene referencias que con toda claridad indican su invención o remodelación a finales del siglo XIII, cuando se puso por escrito la leyenda. Ya hemos comentado que los hagiógrafos, cuando tratan de santos que vivieron en épocas anteriores a la suya, incluyen todo tipo de detalles insignificantes para dar más verosimilitud al relato, como ocurre en este caso en el que se nos indica que era un día festivo de verano y además la iglesia concreta en que oraba. Pero con esta última noticia, su autor se delata, pues, gracias al Fuero de Madrid de 1202 sabemos las advocaciones de todas las iglesias de la villa en esta fecha, probablemente las mismas o alguna más de las que había durante el XII y ninguna de ellas estaba dedicada a Santa María Magdalena. Este error ya fue advertido a principios del xvir por Jerónimo de Quintana, quien lo atribuye al copista que confundió el nombre con el de la Almudena ya que:

[...] como el original de donde se sacó era tan antiguo, y antiguamente se usaban tantas cifras y abreviaturas, estaría esta dicción, Almudena, abreviada, lo cual y la obscuridad de la letra y el tener tanta combinación este nombre con el de Magdalena, fue causa de que el que le escribió trasladase el un nombre por el otro. $\mathrm{Y}$ que sea traslado, y no el original, el que se guarda en aquella iglesia, dícelo expresamente el maestro Villegas, [...]: Porque el que de presente se muestra en la iglesia de San Andrés, de Madrid, es traslado, y no bien escrito ${ }^{86}$.

En otro milagro también se menciona que el santo volvía de rezar de esta iglesia, repitiendo Jerónimo de Quintana un comentario similar, aunque añadiendo que algunos autores piensan que adonde acudía era a otra que había en Carabanchel, lo que él desestima ${ }^{87}$, basándose en la lejanía de ésta. Ciertamente el escribano pudo confundir el nombre de una por el de la otra, aunque estaba bastante claro que La Almudena era la principal advocación de Madrid, tanto en época musulmana cuando fue mezquita, como después de la conquista cristiana al trasformase en iglesia y

86 Gerónimo de QuinTANA, A la mvy antigva noble y coronada Villa de Madrid. Historia de sv antigvedad, nobleza y grandeza. Por el licenciado Gerónimo de Qvintana, Clerigo Presbitero, Notario del Santo Oficio de la Inquisicion, Rector del Hospital de la Latina y natural de la misma villa. Con privilegio en Madrid en la Imprenta del Reyno. Año M. DC.XXIX. (Edición facsímil, Madrid: Artes Gráficas Municipales, MCMLIV), p. 311. Nicolás SANZ MARTínez, op. cit. opina de este comentario que muchas veces se ha aducido para mostrar que el códice es una copia, que, efectivamente, tanto Villegas como Lope de Vega y otros muchos autores posteriores, no tuvieron en sus manos el manuscrito original sino, en el mejor de los casos, una copia de éste realizada para la mejor conservación del códice.

87 Ibid., pp.302-303. 
lo normal es que Isidro fuera asiduamente a rezar al más notable de los recintos sagrados, especialmente en los días de fiesta. Pero a nuestro juicio es mucho más probable que con estas menciones, el autor de la versión que contiene el códice, sin duda un religioso cristiano, pretendiera difundir y divulgar el culto a Santa María Magdalena, que no se documenta en la Península hasta finales del XII, siendo un altar dedicado a ella en 1176, dentro de la catedral del Barcelona, el primer testimonio con que contamos ${ }^{88}$. En Occidente no existen datos sobre su devoción anteriores al siglo $\mathrm{x}$. Su principal centro de culto fue la abadía cluniacense de Vezelay que en el XI pretende poseer su cuerpo, privilegio que se disputa con Éfeso y Provenza, a las que vencerá a finales del XIII, gracias a encontrarse la abadía en el camino de Santiago y resultar por tanto muy visitada por los peregrinos ${ }^{89}$. Aunque desde tiempos muy anteriores existe literatura hagiográfica sobre la santa, su temprano culto en Francia no se difundirá a Italia, Alemania o España hasta el xIII, cuando la personalidad de la pecadora arrepentida, compañera de Jesús en los momentos claves de su biografía, se ajuste a la nueva mentalidad religiosa y a los cambios en los modelos de santidad.

Volviendo al milagro de Isidro, para alivio de los lectores, no enumeraremos ahora toda una serie de ejemplos cristianos y musulmanes con actuaciones opuestas o parecidas (para lo que remitimos al relato anterior), ya que los paralelos más cercanos los hemos encontrado en la mitología popular del norte español; nos referimos al mito del cazador negro. Un cazador - que en las versiones vascongadas suele ser un cura o abad (Martín-abade), otras veces un personaje llamado Mateo-txistu (Guipúzcoa), Juanito-txistularia (Vizcaya) o como el las suletinas el rey Salomón, aunque en Cataluña se le denomina simplemente "el mal cazador", o el "Cazador errante" -, cuando está dentro de una iglesia celebrando-asistiendo a misa oye como sus perros que ha dejado en la puerta ladran a una liebre que pasa cercana. El cazador abandona la misa para seguirla, detrás de ella corren también los canes. Por su acto de impiedad queda maldito y desde entonces persigue inútilmente a la liebre, sin poder detenerse, ni alcanzar nunca su objetivo (en Cataluña se dice que tarda siete años en dar la vuelta al mundo, mientras que en País Vasco se asegura que en las noches de vendaval se pueden oir los aullidos de

88 Emilio SÁEZ, Advocaciones religiosas en la Barcelona altomedieval (siglos IX-XII) (Barcelona: CSIC, 1976).

89 Helen Meredith GARTH, Saint Mary Magdalene in mediaeval literature (Baltimore: The Johns Hopkins Press, 1950), p. 103. Véase también Carmen Bernabé Urbieta, María Magdalena. Tradiciones en el cristianismo primitivo (Estella: Ed. Verbo Divino, Institución San Jerónimo 27, 1994). 
la jauría atravesando los bosques) ${ }^{90}$. Un relato similar, aunque todavía no cristianizado por la mención a la iglesia, se encuentra también en Francia y Alemania, donde se dice que las noches de tempestad recorre el espacio un cazador salvaje seguido de una procesión de almas, se trata de un personaje mítico o legendario, al que Julio Caro Baroja encuentra cercanos paralelos con el mito de Odín.

Mito y milagro parecen dos versiones de una misma trama que sin embargo presenta una oposición casi perfecta, muy semejante a la que José Luis Mingote señaló entre los ángeles labradores y las lamias en el anterior relato. No deja de ser significativo el hecho de que los muchachos que advierten del peligro a Isidro le llamen padre, aunque jamás en ninguna hagiografía se mencione que terminará ingresando en alguna orden monástica. Los comentaristas se inclinan a creer que era un título que se daba a las personas de avanzada edad y a partir de esto deducen la larga vida del patrón de Madrid, pero también pudiera deberse a la influencia del mito que, como hemos mencionado, en más de una versión tiene como protagonista a un cura o abad. Si en un caso el personaje es cazador, en el otro, agricultor. En ambos relatos, mito y milagro, a sus protagonistas, les incita a abandonar la iglesia el reclamo de un animal; al cazador una presa, a Isidro el ataque de un lobo a su burro doméstico. El cazador interrumpe la misa para seguir a la liebre y queda maldito, no logrando jamás alcanzarla (en algunas versiones palentinas es el diablo el que ha tomado esta forma), el labrador permanece orando y Dios le premia, salvando su jumento del ataque del lobo.

\section{MULTIPLICACIÓN DE ALIMENTOS PARA DAR DE COMER A UN POBRE EN SU CASA}

4. [...], siempre rebosaba misericordia en su corazón y nunca dejaba de dar limosna en la medida de sus posibilidades. Y así, un sábado, habiendo dado ya a algunos pobres una piadosa limosna de la olla de su cocina en proporción a lo que podía, se presentó de repente un desventurado pidiendo que se le diese alguna limosna. Sin embargo, ya que Isidro no disponía de nada para darle, movido por su excesiva compasión, suplicó humildemente a su esposa: "Te ruego, por Dios, queridísima esposa, que si queda alguna ración de comida, se la des como limosna a este pobre.. Pero ella misma a sabiendas de que no había quedado nada, fue directamente para mostrarle que la olla de la cocina estaba vacía; sin embargo, puesto que el piadosísimo designio de Dios quería satisfacer el deseo de su devoto siervo, la mujer encontró la olla llena de comida. Y al ver de repente tal

90 Julio Caro Baroja, Algunos mitos españoles (Madrid: Ediciones del Centro, 1974), pp. 73-83; José Miguel Barandiarán, Diccionario de mitología vasca (San Sebastián: Ed. Txertoa, 1984), pp. 141-142. 
prodigio, estupefacta enmudeció momentáneamente, pero llena de regocijo por tan evidente milagro y convencida del favor divino, dio de comer al pobre con gusto y abundantemente[... $]^{91}$

Si para que un santo alcance el reconocimiento popular se le exige una elevada capacidad taumatúrgica que solvente las necesidades de la población, el remedio de la hambruna se coloca sin duda entre los prodigios más demandados y realizados. El propio Jesucristo con la multiplicación de los panes y los peces para alimentar a la muchedumbre que había ido a escucharle inauguró la piadosa tradición ${ }^{92}$. Durante la Edad Media, las periódicas crisis alimentarias y la ausencia de sistemas de cobertura en momentos de carestía, o para la asistencia de los pobres provocaron que la multiplicación de alimentos fuera uno de los milagros más reiterados entre los santos, tanto cristianos como musulmanes. Con los primeros, mayoritariamente monjes, lo normal es que la comida aparezca a la puerta del convento o monasterio, llevada hasta allí por algún desconocido personaje misterioso. Sus beneficiarios pueden ser tanto los propios monjes (como por ejemplo en los casos de de San Benito y Santo Domingo ${ }^{33}$ ), como los que trabajan para ellos (San Lorenzo alimentó con un sólo pan durante diez días a una cuadrilla de obreros que reparaban una iglesia ${ }^{94}$ ), los menesterosos que acuden a pedir, e incluso poblaciones enteras (San Nicolás consiguió sacos de trigo para remediar el hambre de su provincia - Patrás- durante dos años ${ }^{95}$ ). El recurso empleado por el patrón de Madrid, que es el mismo que en el milagro siguiente -es decir, manda que se vuelva a mirar una olla u otro recipiente que se sabía vacío y que tras su súplica aparece lleno- es también muy común y por este procedimiento alimentaron en su casa a unos pobres, Homobono, de quien ya comentamos sus estrechas semejanzas con Isidro; el burgalés obispo de Cuenca, San Julián (1128-1208), o la madre de Santo Tomás de Villanueva ${ }^{96}$ por citar tan sólo algunos ejemplos.

91 Pp. 118-119.

92 José María Bover y Francisco CANTERA Burgos (eds.), Sagrada Biblia.Versión crítica sobre los textos bebreo y griego (Madrid: Biblioteca de Autores Cristianos, La editorial Católica, 1961), Mateo 14,3-23, Marcos 6, 30-46, Lucas 9, 10-17 y Juan 6, 115. Otra multiplicación milagrosa de panes y peces es relatada en Mateo 15, 32-39 y Marcos 8, 1-10.

93 Santiago de la VORÁGINE, op. cit., pp. 203 y 447.

94 Ibid., p. 466.

95 Ibid., p. 39.

96 Pedro de RiBadeneYra, op. cit., vol. -1, p. 306 (Homobono); vol. I, p. 294 (San Julián), vol. III, p. 40 (madre de Santo Tomás). 
Entre los musulmanes, la hospitalidad y el atender y agasajar con comida y bebida a todo el que se acerque a la casa, incluso aunque nada se tenga es una cualidad muy valorada y por supuesto los santos hacen gala de ella. Así se comportaba Abū-l-Haŷŷaŷ ${ }^{97}$, mientras que Sidi Shaykh ${ }^{98}$, el gran santo sahariano, también alcanzó mucha fama como proveedor de alimentos.

\section{MULTIPLICACIÓN DE ALIMENTOS DURANTE LA CELEBRACIÓN DE UNA COFRADÍA}

5. Por disposición de la divina Providencia, acaeció ciertamente, como es habitual en distintos lugares del mundo, que había un cofrade entre los de una cofradía. Y como decidiesen celebrar en una fecha establecida una comida de hermandad, el hombre de Dios, Isidro, que había sido invitado, como acostumbraba a visitar las iglesias para rezar devotamente, se retrasó en exceso. Por lo que llegó cuando había terminado el banquete; y por compasión introdujo también con él en el comedor a algunos pobres que había encontrado a la puerta de la cofradía en espera de la limosna del concurrido festín. Y algunos de los cofrades, al ver este espectáculo, se manifestaron así: "Bendito hombre de Dios, es digno de admiración por tu parte que introduzcas contigo a esos pobres, cuando no queda nada, salvo la ración que se te ha reservadom. Isidro, recibiendo con paciencia estas palabras, respondió de esta manera: "Lo que Dios me ha dado, lo repartiremos a partes iguales entre nosotros . Entonces los que servían la mesa fueron a la olla para traerle la ración reservada y la encontraron llena a rebosar de guiso de carne y, al ver el milagro obrado de repente, quedaron extraordinariamente asombrados y por el momento guardaron silencio, reservando la noticia para mejor ocasión, y con gozo y alegría sirvieron tanto al varón de Dios como a los que le acompañaban la ansiada comida, hasta hartarlos. La comida fue hasta tal punto abundante que incluso con las sobras invitaron a otros pobres. Acabado el banquete, el servidor de Dios levantó las manos al cielo y bendijo el nombre del Señor, sin dejar de mencionar a los benefactores. Y después, despidiéndose de los comensales, se apresuró a ir a la cercana iglesia de Santa María Magdalena para dar muchas gracias a Dios, cuyo don ya le había socorrido misericordiosamente en sus necesidades en el momento oportuno. Todos los que habían estado en la casa, tanto los cofrades como los sirvientes, al percatarse con clarividencia del milagro realizado tan de repente, vivamente impresionados y alabando el nombre del Señor, supieron que el hombre de Dios era en verdad su siervo. [...] «El que hace levantar a un menesteroso del polvo y alza a un pobre del cieno, que se siente con los príncipes y ocupe el trono de la gloria". Máxima que sabemos se ha cumplido en este auténtico siervo de Dios, no sólo espiritual, sino también corporalmente. En efecto, su pequeño pero glorioso cuerpo reposa hoy deposita-

97 Jaime OLIVER Asín, op. cit., p. 78.

98 Houari Touati, Entre Dieu et les Hommes. Lettrés, saints et sorciers au Maghreb (17º siècle) (Paris: Éditions de L'École de Hautes Études en Sciences Sociales, 1994), p. 200. 
do en la iglesia de San Andrés Apóstol, entre los Apóstoles Príncipes gloriosos, donde tiene un hermoso sepulcro para gloria humana, y en los cielos, premiado con un lugar en la gloria, es ensalzado eternamente con todos los Santos ${ }^{*}$.

En este último milagro de la leyenda de San Isidro se reiteran algunas características ya comentadas en los anteriores, por lo que sólo las enumeraremos brevemente. El relato, al igual que vimos cuando los bueyes araban solos parece una composición independiente destinada a ser leída de forma aislada, pues cuenta con una caracterización del escenario y un epílogo final. Como en todas las demás narraciones, exceptuando la que se desarrolla en su casa, con su esposa como único testigo, el comportamiento de Isidro es atípico y antisocial; no sólo llega a la comida cuando ya han acabado los demás, sino que, sin enterarse antes de si quedan o no sobras introduce con él a un grupo de pobres, lo que le vale la burla socarrona de algunos cofrades. La forma en que se multiplican los alimentos, volviendo a mirar una olla que se creía vacía, también sigue el mismo patrón que en el caso anterior, al igual que la certeza, tras el prodigio, de que Isidro es un santo (ssupieron que el hombre de Dios era en verdad su siervo"), o el silencio momentáneo sobre el suceso, que sólo se comenzará a contar cuando él no esté delante. La anacrónica mención a la cercana iglesia de Santa María Magdalena tampoco es nueva, pero ahora se completa con otro dato cronológicamente muy improbable y que en realidad es el que da sentido a esta nueva variante del milagro anterior. Nos referimos al ya aludido escenario: la celebración o banquete de una cofradía.

Más arriba decíamos que, en la Edad Media, la ausencia de un tipo de cobertura organizada a nivel estatal, municipal o religioso provocó que para solventar determinadas necesidades sociales se recurriera al poder taumatúrgico de los santos. Pero desde tiempos muy remotos existieron asociaciones profesionales o religiosas, en las que sus miembros practicaban una solidaridad para cubrir necesidades o contingencias, como carestías alimentarias o monetarias, enfermedad, muerte, asistencia a los pobres, etc. (de este tipo eran los collegia romanos). Las cofradías cristianas tuvieron un rápido inicio en Oriente, conociéndose ya en el siglo IV los spondaei, asociaciones de cristianos que vivían entre sus correligionarios pero con una vida más austera. Asimismo se cita como precedente la Gilda germánica que tenía como objeto una mutua defensa y asistencia entre sus miembros, mientras que en Francia, en el concilio de Nantes (895) ya se mencionan.

Entre los musulmanes las cofradías son de un carácter diferente a las

99 Pp. 119-120. 
cristianas, ya que se forman alrededor del fundador y sus seguidores o discípulos, transmisores de sus enseñanzas, creando una tariqa, "senda hacia Dios", que es lo que se traduce por cofradía. Cuentan normalmente con dos tipos de participantes: unos de primer orden, mucho más comprometidos que viven en comunidad y cuyo status se podría comparar al de los monjes cristianos, y otros, adeptos laicos que desarrollan normalmente su vida social y familiar, cumpliendo tan sólo con determinadas cuotas y obligaciones como miembros de la asociación ${ }^{100}$. Entre sus ritos cuentan con la celebración de un banquete anual en el que se sacrifica un cordero macho que cuecen en una olla, una vez deshuesado y que luego comerán los cofrades acompañado con arroz, quedando los restos para los pobres ${ }^{101}$; ceremonia que perfectamente podría ajustarse a la caracterización hecha en el relato, si no fuese porque la fecha en que se sitúa, siglo XII, es demasiado temprana. Efectivamente, aunque sus orígenes orientales se remontan al IX, a Occidente no llegaron las primeras hasta el XII y su difusión y generalización realmente se produjo a lo largo del XIII ${ }^{102}$. En estos dos siglos Madrid, que ya era una villa cristiana, probablemente había perdido buena parte de su notoriedad anterior y resulta casi imposible pensar en la existencia de una fundación de este tipo.

En la España cristiana, tras la invasión islámica debieron desaparecer las cofradías u organizaciones similares de época visigótica, sin refundarse durante la reconquista, ya no tenemos noticias de su constitución hasta el siglo XII, cuando como el culto a María Magdalena, los cluniacienses, a través de los peregrinos, las difundieron por todo el camino de Santiago. Pero en estas fechas, las referencias son contadas, conociéndose algunas de carácter caballeresco como las de Uncastillo, Monreal o Barbastro y otras con un matiz religioso-benéfico: Canizo en la villa de Toro, Santa Eulalia en Barcelona y Santa Cristina en Tudela (esta última de especial interés por conservarse las ordenanzas) ${ }^{103}$. Otras, de carácter profesional o corporativo, pronto dieron lugar a la aparición de los gremios. Todas ellas se originaron en ciudades o villas del norte peninsular, de bastante

100 Alexandre POPOVIC y Gilles Veinstein (coords.), Las sendas de Allab. Las cofradias musulmanas desde sus origenes basta la actualidad (Barcelona: Ediciones Bellaterra, Biblioteca del Islam Contemporáneo. Serie Ibn Jaldún, 1997), pp. 11 y ss.

101 Gerhard BöwERING, "Reglas y rituales sufíes", Las sendas de Allab. op. cit., pp. 175-195.

102 Véase Eric GEOFFroy, "La aparición de las sendas: las jirqa primitivas" (siglo XII-principios del XIII) y Sossie ANDEZIAN, "Argelia, Marruecos y Tunicia", Las sendas de Allab, op. cit., pp. 57-70 y 477-500 respectivamente.

103 Antonio RUMEU DE ARMAS, Historia de la previsión social en España. Cofradias, gremios $y$ bermandades (Barcelona: Ediciones "El Albir", 1981), pp. 39-55. 
mayor importancia o desarrollo urbano que Madrid, donde con bastante seguridad no existieron en el siglo XII. Entre los milagros póstumos de la segunda sección del códice ${ }^{104}$ hay uno en el que la multiplicación de alimentos para los pobres tiene un esquema idéntico, pero se menciona que la cofradía era la de San Isidro, por lo que habría que pensar que ya a finales del siglo XIII existía en Madrid, aunque no hay ningún otro documento en que se nombre ésta u otra con diferente advocación.

Su fundación no requería ningún tipo de licencia real o eclesiástica y por sus funciones y carácter democrático y plebeyo, pronto se convirtieron en focos de poder opuestos, o en detrimento, a los intereses monárquicos. Por ello, so pretexto de que en la fiesta anual del patrón, durante el preceptivo banquete, se cometían todo tipo de desmanes y excesos y que, además, eran nidos en los que se ocultaban y protegían bandidos y bandoleros que llegaron a formar su propia hermandad, fueron prohibidas en 1214 por el rey francés Francisco I y también durante el xiII por los monarcas castellanos y aragoneses, lo que no impidió que se robustecieran interiormente manteniendo sus normas y costumbres, siempre en contra del poder real.

La mención a que San Isidro pertenecía a una y, aunque sin puntualidad asistía al banquete anual, se debe considerar como un tipo de propaganda o intento de difusión, al igual que ocurre con la referencia al culto a Santa María Magdalena. De hecho, el inicio del milagro así parece indicarlo: "como es habitual en distintos lugares del mundo, que había un cofrade entre los de una cofradíam. No se menciona el nombre de la hermandad, ni de su patrón, pero sin duda, la asociación era de carácter religioso-benéfico. En estas, lo normal era que las sobras del banquete anual se repartieran como caridades entre los pobres y por ello había un grupo esperando a la puerta. Isidro hizo mal incorporándose tarde a la comida, pero el resto de los cofrades también se estaban excediendo y saltando las normas, cuando alegremente se comieron las porciones que hubieran tenido que reservar a los pobres e incluso se mofaron del santo cuando entró con ellos. Si le reservaron su parte fue porque todos los cofrades, además de pagar sus cuotas, estaban obligados a costear los gastos de la fiesta mayor, especialmente el sacrificio del toro o carnero que se servía guisado.

El colofón final en el que se ensalza la figura del hombre humilde que termina situado entre los Apóstoles Príncipes, es de un tono moderno e indica el carácter popular del culto a San Isidro, el labrador que supera en su santidad a aristócratas y monjes. Representa un tipo de valores que en el cristianismo sólo se conocieron a partir del siglo xiII,

104 P. 139. 
aunque entre los santos del Magreb tiene precedentes ya desde el XI. Es lo que con acierto Sossie Andezian ${ }^{105}$ denomina "la revancha del pueblo", que a partir de este momento empieza a contar con santos patronos cercanos y que proponen un modelo de santidad no sólo accesible a las clases bajas, sino sobre todo a su servicio.

\section{MUERTE, ENTIERRO Y TRASLACIÓN DE SAN ISIDRO}

Tanto en las hagiografías islámicas como en las cristianas se da una importancia primordial al relato de los últimos momentos de la vida del personaje biografiado. El tener una buena muerte, en paz con Dios y los hombres, abandonando el mundo tras dejar preparada esta marcha, tanto espiritual como materialmente es la nota más común que también comparte San Isidro:

6. Así, pues, este hombre que sobresalía por sus buenas costumbres, que tenía una esposa legítima y un hijo, que era un buen administrador de su casa, como correspondía, y que llevó una vida encomiable, mereció alcanzar una muerte más loable por la generosidad del Señor. [...] cayo enfermo en cama y al darse cuenta de que estaba muy cerca el último día de su esforzada vida, después de recibir la extremaunción, haciendo testamento de sus bienes terrenales, aunque eran escasos, y aleccionando a su familia en el amor del Señor, como convenía, y después de darse golpes de pecho y unir sus manos y cerrados sus ojos, hizo la señal de la cruz y entregó su humilde alma cristiana a su Creador [...].

Fue enterrado en el cementerio de San Andrés Apóstol, desde cuya iglesia, en tiempos de su habitual peregrinación para la oración, se marchaba para dirigirse finalmente a su trabajo desde la Villa. Allí estuvo enterrado mucho tiempo su cuerpo, a saber, cuarenta años, sin que casi nadie lo visitase. Y así permaneció oculto tanto tiempo que, en época de lluvias, un riachuelo que corría por encima, arrastrando la tierra, entró en el hoyo de la sepultura. Pero el Señor Misericordioso, [...] no permitió que el cabello o parte alguna del cuerpo de su fiel siervo sufriera daño ${ }^{106}$.

El varón de Dios, Isidro, tras su modesta vida muere cristianamente. $\mathrm{Si}$ en los relatos anteriores resultaba difícil encontrar un claro mensaje moral o unas pautas de conducta a seguir, en esta nueva caracterización aparece como un hombre casado, padre y trabajador, un buen administrador de su casa" que dispone de sus bienes y alecciona a su familia antes de morir, todo un modelo para las clases populares laicas. Pero su leyenda,

105 Sossie Andezian, "Argelia, Marruecos y Tunicia", Las sendas de Allah, op. cit., pp. 490.

106 Pp. 120-121. 
es decir, los cinco milagros recogidos en el códice, no conllevaron al reconocimiento de su santidad en vida y no sólo no recibió culto tras ésta, sino que fue enterrado en un lugar no sagrado y olvidado durante cuarenta años.

La verdadera vida de un santo comienza tras su muerte, especialmente entre los cristianos, menos proclives que los musulmanes a reconocer y dar algún tipo de veneración a individuos todavía vivos. Entre los muertos, el culto se centra en su sepulcro, lugar al que se acude para obtener la mediación milagrosa, práctica que en ambas religiones en la Edad Media alcanzó un elevadísimo desarrollo, aunque fue mayor en la cristiandad europea, donde las iglesias para poder ser consagradas requerían tener las reliquias de algún santo. Se crea así un auténtico tráfico de éstas y numerosas disputas y traslados en reivindicación de la posesión de las "auténticas" entre diversas órdenes religiosas y ciudades europeas. En la recién tomada villa madrileña, se siguió la práctica habitual de consagrar a la nueva religión dominante las antiguas mezquitas. La Almudena, el principal centro religioso musulmán se convierte en iglesia de la villa, conservando su carácter protagonista. Su advocación a una Virgen, la patrona de Madrid soluciona el problema de las reliquias, pero se requiere alguna imagen que autentifique la antigüedad de la advocación y naturalmente ésta aparece; ;habiendo permanecido oculta en una hornacina practicada en las murallas durante los tres siglos de dominación islámica! La hagiografía de San Isidro nuevamente tiene un peso decisivo ante los escasos datos históricos sobre el Madrid medieval y el hecho de que se mencione en el códice que en San Andrés fue enterrado nuestro santo provoca que los historiadores supongan que se trataba de la única iglesia mozárabe del Madrid musulmán. Pero, sin necesidad de retorcer datos o argumentos y conociendo la codicia generalizada por asegurarse reliquias y santos patronos, también se podría pensar que, al remover los restos del cementerio anexo a la mezquita, probablemente para su correcta cristianización, se encontró un cuerpo incorrupto que naturalmente no se podía desaprovechar. La identificación de este cadáver con el personaje de una leyenda oral sobre un santo que vivió en Madrid, al cual naturalmente se cristianiza y para mayor solvencia se escribe y completa su hagiografía, trasladándole a un lugar preferente del templo, no son más que los pasos lógicos para obtener el demandado patrón.

7. Por compasión divina, aconteció una vez que a un compadre suyo, que vivía junto a la antedicha iglesia, se le apareció Isidro una noche aconsejándole que comunicase a los feligreses de aquella iglesia que, por orden del Señor, su cuerpo debía ser exhumado de la susodicha tumba y colocado con honor en la iglesia del citado San Andrés Apóstol. Sin embargo, aquel compadre suyo, acordán- 
dose de los tiempos en que vivió humildemente y poniendo en duda su buena fe, no quiso comunicar el encargo de la aparición. Por esta razón cayó enfermo hasta el día del traslado del cuerpo de Isidro.

Por disposición de Dios, por segunda vez, se apareció de noche a una mujer casada de buena fe y le aconsejó, como queda dicho que su cuerpo debía ser trasladado por el pueblo a la mencionada iglesia. Advertencia que la referida mujer de buena fe comunicó al pueblo, y puesto que algunos había conocido la honrada y justa vida de Isidro, o bien había oído hablar de ella, todos a una excavaron con prontitud en su tumba. Y, encontrando su cuerpo intacto y sin daño, y su mortaja en buen estado y entera, desprendiendo un suave olor de incienso, con gran regocijo y alabanzas dieron muchísimas gracias a Dios [...] por haberse dignado revelar a a su humilde y fiel siervo, y colocar la reliquia de su elegido en compañía de sus elegidos, los Príncipes de la Iglesia. Y así, tanto los caballeros devotos como todos los demás, con alegría general, colocaron, con el debido honor, el cuerpo del bienaventurado varón en la iglesia del referido Apóstol, "al lado de los altares de los Santos Apóstoles en una nueva tumban ${ }^{107}$.

El relato es evidentemente cristiano, aunque no deja de tener estrechas conexiones con los islámicos. En ambas religiones, los santos, una vez muertos, se comunican con los vivos en apariciones nocturnas, a través de los sueños, también coinciden en que su preocupación prioritaria sea el reconocimiento de su condición y el inicio del culto en el lugar del sepulcro. Cuando, como en nuestro caso, el enterramiento no se ha realizado en un lugar sagrado urge la traslación. Así Gonzalo de Berceo en el tercero de Los milagros de Nuestra Señora, "El clérigo y la flor" ${ }^{108}$, nos narra cómo un clérigo que murió en extrañas circunstancias es enterrado fuera de la iglesia, la Virgen manda a sus compañeros que le desentierren y cuando lo hacen, se encuentran que su cuerpo está incorrupto y tiene una flor en la boca, siendo ante tal prodigio inmediatamente trasladado al lugar sagrado. Entre los musulmanes no sólo se dan este tipo de casos sino que incluso, como en la narración que nos ocupa, es frecuente que el santo tenga que aparecerse a dos personas para lograr su propósito, normalmente porque la primera duda de la autenticidad de la visión-sueño, a veces porque en su localidad ya existe un santo patrón y el nuevo aspirante a recibir culto deberá buscar a un individuo de otro lugar que transmita su deseo ${ }^{109}$. En nuestro caso las dudas del compadre provocan el primer "milagro-castigo" de San Isidro que en ésto también mantiene la tónica de los santos islámicos; el vecino cae enfermo y no

107 Pp. 121-122.

108 Antonio GARROSA RESINA, Magia y Superstición en la literatura castellana medieval (Valladolid: Biblioteca de Castilla y León n. ${ }^{\circ}$ 1, 1697), p. 117.

109 Federik M. DENNY, op. cit., pp. 87-88 y Halima FERHAT y Hamid TRIKI, op. cit., p. 41. 
sanará hasta que el cuerpo sea trasladado. En su segunda aparición que también sucede de noche, selecciona a una mujer casada de buena fe, que efectivamente comunica al pueblo su visión. La semiolvidada leyenda hagiográfica se reaviva, algunos dicen que le conocieron en vida, otros, tan sólo por referencias, pero la actuación es unánime y todos a una (caballeros devotos y el resto del pueblo) excavan la tumba. El agradable olor que desprende el cuerpo será característica muy reiterada entre los santos cristianos, identificándose con "el olor a santidad", muy significativo para el reconocimiento de la condición.

Tras la vida de Isidro prosiguen unas narraciones donde se cuentan milagros póstumos, los himnos y otra serie final de prodigios que claramente se identifican con los prototipos cristianos del xiII. Nosotros, para finalizar, incluiremos tan sólo lo sucedido durante la traslación y cómo, aunque sin reconocimiento oficial eclesiástico, Isidro comienza a tildarse de santo, siendo aclamado y venerado como patrón de Madrid.

9. [...] En efecto, en la exhumación del sagrado cuerpo para trasladarlo a la iglesia de San Andrés, el Señor se digno manifestar el siguiente prodigio: todas las campanas de aquella iglesia, volteadas por sí mismas sin que nadie las manejase y sin la ayuda de ningún artilugio, replicaron a la vez, hasta que el cuerpo quedó depositado en el sepulcro, como si hubiesen sido movidas por las manos de los hombres. Tanto los contemporáneos como los de las generaciones siguientes vieron en esto un milagro divino y otorgaron a Isidro el título de Santo, con absoluta convicción, sin la autoridad eclesiástica. Y así, tanto por los hombres como por las mujeres, se le llamó universalmente San Isidro [...].

[...] Unos pobres tullidos e invidentes que mendigaban en el camino real y que tenían su puesto cerca de la Villa, cuando oyeron la noticia de un prodigio tan grande, con fe ciega y alegres, se congregaron junto a la fosa donde Isidro había estado enterrado y, recogiendo con fe tierra y restregándola por sus miembros contrahechos, recibieron el don de la curación, queriendo así la Misericordia Divina poner de manifiesto la santidad de su siervo ${ }^{110}$.

Muy brevemente, sólo añadiremos que mientras el voltear de campanas durante el traslado es un tipo de milagro típicamente cristiano, la conducta de los mendigos y lisiados restregándose con la arena del sepulcro, aunque también aparece en esta religión es sobre todo una práctica curativa empleada por los musulmanes. La forma en que Isidro pasa a ser reconocido como santo, sin aprobación eclesiástica es asimismo habitual en la época, sobre todo teniendo en cuenta que se trata del patrón de una villa de escaso protagonismo político y religioso; será necesario que Madrid se convierta en la sede de la corte para que llegue la canonización.

110 Pp. 122-123. 
Como recapitulación queremos destacar nuevamente el carácter sincrético y conciliador que la leyenda de Isidro, el varón de Dios desempeñó en Madrid entre los siglos XI y XIII, cuando sus habitantes, moros judíos y cristianos pasaron del dominio islámico, al cristiano. Así, en los diversos relatos que componen ésta parte del códice podemos encontrar una curiosa evolución. En tres de sus milagros (cuando alimenta a las palomas, los bueyes aran solos y multiplica los alimentos en su casa) nos encontramos con un personaje legendario que no responde a los prototipos de santos cristianos de las supuestas fechas en que se forjó su leyenda, sino más bien a los islámicos. Pero en los otros dos (cuando no abandona la iglesia para proteger a su burro y multiplica los alimentos en el banquete de una cofradía), que son variantes de los otros contados, además de en las narraciones de su muerte y traslación, el hagiógrafo, probablemente un monje con evidentes influencias de la orden de Cluny, rescata y actualiza la figura, cristianizándola plenamente, según el nuevo tipo de religiosidad y modelo de santidad imperante en su época.

En el presente trabajo se analizan los cinco milagros realizados en vida por San Isidro (patrono de Madrid), según un manuscrito que recoge una tradición oral y se fecha a finales del siglo xiIr. Se destaca el carácter pluricultural de la villa medieval, en transición entre la dominación islámica y la cristiana, y cómo su patrón responde a un modelo de santidad que encuentra paralelos en los prototipos de los santos de ambas religiones en la época. San Isidro se presenta como un santo sincrético y conciliador de carácter eminentemente popular, capaz de responder a las necesidades e inquietudes de las clases populares madrileñas de la Edad Media.

The author analyzes the five miracles that Saint Isidre, patron of Madrid, performed in life, according to a manuscript from the late 13th century that echoes an oral tradition. She remarks on the multicultural character of the medieval town, in a period of transition from Muslim to Christian rule, and the extent to which the representation of Saint Isidre fits a model of sainthood that cuts across religious boundaries: it resembles the representation of other saints, Chistian as well as Muslim. Isidre was a syncretic, conciliatory, popular saint who was able to respond to the needs and concerns of Madrid's lower classes in the Middle Ages. 